\title{
A Modeling Study of Perched Water Phenomena in the Unsaturated Zone at Yucca Mountain
}

\author{
Y.S. Wu, A. C. Ritcey and G. S. Bodvarsson \\ Earth Sciences Division \\ Lawrence Berkeley National Laboratory \\ Berkeley, California, U. S. A.
}

\begin{abstract}
The purpose of this paper is to illustrate the use of a multiphase subsurface flow model to study perched-water phenomena in vadose zones. Modeling studies are based on perched water data observed during field studies on the unsaturated zone (UZ) at Yucca Mountain, Nevada. Perched water data have been compiled, analyzed, and incorporated into a three-dimensional (3-D) UZ flow model developed to investigate perched water phenomena at Yucca Mountain. A conceptual model of perched water occurrences is discussed, and a series of comprehensive computer modeling studies on perched water at the site are presented. The model has been calibrated using perched water data observed in six boreholes, and reproduces water-perching conditions in the unsaturated zone of the mountain. Both steady-state and transient simulations have been conducted. The steadystate simulation results are in agreement with the observed perched water data, including water saturation and potential profiles and perched water elevations. Transient numerical pumping tests were performed using pumping testing data collected in the field from two boreholes. The numerical pumping test results match observed water levels collected during pumping and recovery periods.
\end{abstract}

Key Word: Perched water, vadose zone hydrology, numerical modeling, unsaturated flow, fractured porous media, and Yucca Mountain.

\section{Introduction}

Considerable progress in vadose zone hydrology has been made in recent years due to the research in soil science and also as a result of environmental concerns over the uncontrolled release of hazardous compounds to the subsurface environment. Computer modeling studies of contaminant migration and remedial measures in the vadose zone have played a critical role in addressing these issues. The capabilities of flow and transport models have been improved tremendously, evolving from solving the basic Richard's unsaturated flow equation to simulation of coupled processes of multi-phase, multi-component, and non-isothermal fluid flow and chemical transport. One of the new 
areas in vadose zone hydrology is the field of perched water studies. This area has recently received increased attention, particularly in the arid western United States, where thick unsaturated zones and highly heterogeneous, fractured rock can lead to the development of significant perched water zones. One such site, located at Yucca Mountain, Nevada, is currently under consideration by the U.S. Department of Energy as a potential site for the storage of high level radioactive waste.

Since the middle 1980's, the U.S. Department of Energy has pursued a program of site characterization studies designed to explore the geological, hydrological, and geothermal conditions in the unsaturated and saturated zones of the mountain. The unsaturated zone at Yucca Mountain varies between about 500 to $700 \mathrm{~m}$ in thickness, depending on local topography. The potential repository would be located in the highly fractured Topopah Spring welded unit (TSw), 200 to $300 \mathrm{~m}$ above the water table. During field investigations, several perched-water zones have been encountered (Burger and Scofield, 1994; Striffler et al., 1996; and Rousseau et al., 1996). The presence of perched water bodies within Yucca Mountain has important implications for travel times and flow paths of water through the unsaturated zone, and could pose potential problems for the construction, operation, and performance of the repository. Thus, it is necessary to investigate perched water and its implications in order to understand the unsaturated zone hydraulic system at Yucca Mountain.

There exist few experimental or field studies on the perched water phenomena in unsaturated fractured rocks in the literature, although numerical modeling studies were reported in unsaturated layered soils (Forsyth et al., 1995; Kirkland et al., 1992). This may be due to the fact that unsaturated zone hydrology, in particular for fractured rocks, is still under development. However, several conceptual models of perched water occurring at Yucca Mountain have been presented (Hoxie, 1989; and Rousseau et al., 1996). Some theoretical analyses were also conducted to predict perched volumes using a 2-D numerical model (Hinds et al., 1997). Perched water may be defined as a saturated zone that is above or not directly connected to the static water table (Freeze and Cherry, 1979). Two conditions must be satisfied for a perched water body to exist in a vadose zone of fractured media. The first is that liquid saturation within a perching zone must be sufficiently high to initiate fracture flow (assuming that fractures are present), and secondly the water-phase pressure within the perched zone must be equal to or greater than static atmospheric gas pressure at the same elevation. Under these conditions, water will flow freely from a borehole or tunnel that intersects a perched water body.

Perched water may accumulate where adjacent formation units have disparate hydraulic conductivities such as when water migrating downward through a more permeable rock reaches a much less permeable rock through which flow paths are limited. It may occur in a permeable layer overlaying a relatively impermeable layer, or in a well-connected fractured unit overlaying a locally unfractured or poorly connected fractured unit. Perched water may also form along a dipping, low-permeability horizontal plane that is adjacent to a fault that acts as a capillary barrier to downdip water flow. 
The presence of perched water bodies in the vicinity of the potential repository at Yucca Mountain has many implications, and at the same time it may provide invaluable insights into water movement, flow pathways, or surface infiltration history of the mountain. First it implies that water particles may not travel vertically through the unsaturated zone to the water table directly, but has somehow been trapped or diverted laterally. As a result, non-uniform recharge rates are expected at the water table. Another concern is that perched zones may divert water around low-permeability zeolitic layers, a lower formation unit, underlying the potential repository horizon. By-passing of these units, which are thought to have substantial capacity to retard radionuclide transport, could have important implications for the capability of the geologic system to mitigate radionuclide releases to the environment. In addition, a perched body, if close to the repository, may affect thermo-hydrological conditions at the repository during thermal loading from decayed heat of high level radioactive nuclear wastes.

In this study, we have conducted a series of 3-D modeling simulations using the TOUGH2 code (Pruess, 1991) and available perched water data from six boreholes (UZ14, SD-9, NRG-7/7a, G-2, SD-9, and SD-12). These modeling studies are designed to investigate the perched water occurrences at the Yucca Mountain site. In these simulations, both the generalized effective continuum method (ECM) and the more rigorous dual-permeability conceptualization have been used to account for fracture and matrix interactions (Pruess et al., 1990a and 1990b; Wu et al., 1996a). As indicated by residence times derived from geochemical data (Yang et al., 1996), perched water bodies at Yucca Mountain may have existed for thousands of years, and are currently present under steady-state or quasi steady-state conditions. Under such conditions, the ECM will provide a reasonable approximation for fracture/matrix interactions (Wu et al., 1996b; Doughty and Bodvarsson, 1996; 1997 and this issue).

A spatially varying surface infiltration map (Flint et al., 1996) is used to describe areally distributed net infiltration at the land surface. Perched water data observed in the field were used to calibrate the model in terms of matrix and fracture permeabilities, capillary functions, and relative permeabilities within the perched zones. Calibrated parameter values were within the range of field and laboratory measurements. The steady-state simulation results are in agreement with the observed perched water data in terms of water saturation and perched water locations. Furthermore, the simulation results of a transient numerical pumping test using a 3-D submodel matched water level data observed during field pumping tests.

\section{Perched Water Data}

Perched-water has been intersected in a number of boreholes (UZ-14, NRG-7a, SD-9, and G-2), in the UZ at Yucca Mountain (Striffler et al.; 1996). Perched water was also found at borehole SD-7 (Czamecki; 1995) and (Soeder; USGS, 1995), and wet core was recovered from borehole SD-12 (Patterson; 1996). In addition to the perched water 
information, the measured liquid saturation and water potential profiles available for the selected boreholes were used for comparisons with model simulation results.

The locations of the boreholes are shown in Figure 1; borehole coordinates and related perching information are listed in Table 1. Detailed descriptions of the boreholes and associated perched water data are presented below.

\begin{tabular}{|c|c|c|c|c|c|c|}
\hline \multirow[b]{2}{*}{ BOREHOLES } & \multicolumn{2}{|c|}{$\begin{array}{l}\text { NEVADA } \\
\text { COORDINATES }\end{array}$} & \multirow{2}{*}{$\begin{array}{l}\begin{array}{l}\text { SURFACE } \\
\text { ELEVATION' }\end{array} \\
\text { (masl) }\end{array}$} & \multirow{2}{*}{$\begin{array}{l}\text { TOTAL } \\
\text { DEPTH } \\
(\mathrm{m})\end{array}$} & \multicolumn{2}{|c|}{$\begin{array}{l}\text { UPPER ELEVATION } \\
\text { OF PERCHED }{ }^{4} \text { ZONE }\end{array}$} \\
\hline & $\begin{array}{l}\text { North } \\
\text { (m) }\end{array}$ & $\begin{array}{l}\text { East } \\
(\mathrm{m})\end{array}$ & & & $\begin{array}{l}\text { Elevation } \\
\text { (masl) }\end{array}$ & $\begin{array}{l}\text { Depth } \\
\text { (m) }\end{array}$ \\
\hline UZ-14 $4^{2}$ & 235095 & 170731 & 1349 & 673 & 966 & 383 \\
\hline NRG-7a ${ }^{2}$ & 234355 & 171598 & 1282 & 461 & 821 & $458-461$ \\
\hline $\mathrm{SD}-7^{3}$ & 231328 & 171066 & $1359^{5}$ & 632 & 880 & $480^{5}$ \\
\hline$\overline{\mathrm{SD}-9^{8}}$ & 234086 & 171242 & 1302 & 678 & $889^{4}$ & $413^{4}$ \\
\hline $\mathrm{SD}-12^{9}$ & 232244 & 171178 & $1324^{6}$ & $660^{6}$ & $926^{6}$ & $398^{6}$ \\
\hline $\mathrm{G}-2^{10}$ & 237386 & 170842 & 1554 & 1891 & $1020^{7}$ & $534^{7}$ \\
\hline
\end{tabular}

'EG\&G Energy Measurements (1994).

${ }^{2}$ Geslin et al. (1994).

${ }^{3}$ Rautman and Engstrom (1996a).

${ }^{4}$ Striffler et al. (1996).

${ }^{3}$ Czarnecki (1995) and Soeder (1995).

${ }^{6}$ Patterson (1996).

'Craig. (1995).

${ }^{8}$ Engtrom and Rautman (1996) and Moyer et al. (1995a).

'Rautman and Engstrom (1996).

${ }^{10}$ Maldonado and Koether (1983).

\section{Borehole UZ-14}

Borehole UZ-14 is located in a small alluvial wash called Drill Hole Wash, near the northern end of the potential repository (Figure 1). The surface elevation of the borehole is $1,349 \mathrm{~m}$ and total depth is $673 \mathrm{~m}$. Perched water was encountered during drilling at a depth of about $383 \mathrm{~m}$, near the contact with the basal vitrophyre of the Topopah Spring Tuff. Several pumping tests were conducted on the perched water zone in this borehole (Burger and Scofield, 1994; Striffler et al., 1996). Drawdown from these tests recovered completely after 5.6 days, suggesting that an extensive perched-water body may exist in this area (Czarnecki, 1995). 


\section{Borehole NRG-7a}

Borehole NRG-7a is also located in Drill Hole Wash, with a surface elevation of $1,282 \mathrm{~m}$. The borehole was drilled to a total depth of $461 \mathrm{~m}$ into the top of the Calico Hills formation. Perched water was reached between 458 and $461 \mathrm{~m}$ depth, within a series of highly fractured welded tuffs overlying relatively unfractured, nonwelded tuffs.

\section{Borehole SD-9}

Borehole SD-9 is located adjacent to Drill Hole Wash, with a surface elevation of 1,302 $\mathrm{m}$ and a total depth of $678 \mathrm{~m}$. Perched water was intersected at a depth of $413 \mathrm{~m}$, about 3 $\mathrm{m}$ above the lower nonlithophysal/vitrophyre contact in the Topopah Spring Tuff, and about $157 \mathrm{~m}$ above the water table. The perched water zone was located in highly fractured, welded tuff underlain by less-fractured, non-welded tuff.

\section{Borehole SD-7}

The perched water in SD-7 was found in the bottom portion of the Calico Hills zeolitic unit at an elevation of $880 \mathrm{~m}$, or about $150 \mathrm{~m}$ above the regional water (Soeder, 1995). Analysis of hydraulic testing indicates that the volume of the perched water body volume is small (about $30,000 \mathrm{~m}^{3}$ ), because the water level did not recover to the pre-pumping levels after testing (Luckey, 1995). The Ghost Dance fault appears to block water flow which is being laterally diverted by an eastward dipping altered portion of the zeolitic Calico Hills tuff of the Calico Hills non-welded ( $\mathrm{CHn}$ ) unit, and this water creates the perched water body.

\section{Borehole SD-12}

According to Patterson (1996), the surface barometric signal is attenuated within and below the crystal-poor vitric zone, indicating that a perched or saturated water zone probably exists at this location. Perched water was detected at an elevation of $926 \mathrm{~m}$. (Patterson, 1996). The stratigraphic location of perched water at the contact between the crystal-poor nonlithophysal zone and the crystal poor vitric zone is consistent with the location of perched water found in other North Ramp boreholes (Patterson, 1996.

\section{Borehole G-2}

Borehole G-2 is located at the northern end of Yucca Mountain (Figure 1). The borehole has a surface elevation of $1,554 \mathrm{~m}$ and extends to a total depth of $1,891 \mathrm{~m}$ below land surface (M\&O, 1995). In 1981, a composite water level (Czarnecki et al., 1994) was detected at an elevation of $1,032 \mathrm{~m}$, and since then the water level has declined by 
approximately $12 \mathrm{~m}$ to an elevation of about $1,020 \mathrm{~m}$ (Craig, 1995). Although several hypotheses exist, water level data suggest the presence of a perched or semi-perched water body that may contribute to the composite water level.

\section{Perched Water Geochemistry}

Chemical data from the perched water and matrix pore waters of the unsaturated zone was collected at Yucca Mountain and has been used to estimate perched water ages (Yang et al., 1996). There exsist a wide range of chemical data, reversals in pore waters from boreholes at depth, high values of ${ }^{14} \mathrm{C}$ in pore-water in the Calico Hills Formation, and chemical disequilibrium (e.g., chloride) between perched water and pore-water. This indicates that fast flow with little interaction with matrix pore waters is the main source of perched water. Rapid transport through the PTn and into the TSw unit is supported by evidence of bomb-pulse ${ }^{36} \mathrm{Cl}$ in the exploratory study facility (ESF), an underground tunnel at Yucca Mountain, (Fabryka-Martin et al., 1996). Furthermore, $\delta \mathrm{D}$ and $\delta^{18} \mathrm{O}$ values show that perched water has undergone very little evaporation before infiltration and is slightly heavier than saturated zone water (Yang et al., 1996). These chemical data provide invaluable information for water travel times and pathways to the perched water body (Wu et al., 1997b).

A full interpretation of the available water chemistry requires an assessment of possible water-rock interaction, including inieraction with the surface alluvium and calcretes, the tuff matrix, high-temperature fracture coatings, and secondary mineralization. In terms of understanding the geochemical behavior of the unsaturated zone at Yucca Mountain, chlorine is the simplest element to study because it is not incorporated in any minerals of volumetric importance and its abundance in unaltered tuffs is quite low (Sonnenthal et al., this issue). Therefore, an understanding of the chloride balance in the mountain can be used to constrain flow, transport, and mixing phenomena in Yucca Mountain as a precursor to modeling much more complex systems involving reactions between rock, water and gas. ${ }^{14} \mathrm{C}$ data indicate that perched water ages range from 4,000 to 7,000 years accounting for caliche dissolution as indicated by $\delta^{13} \mathrm{C}$ data (Yang et al., 1996). $\delta^{18} \mathrm{O}$ data also support perched water residence times of less than 8,000 years (Yang et al., 1996). According to Yang et al. (1996), differences in chloride concentrations between water sampled from boreholes during pumping tests and pore water extracted from the rock matrix show that recharge probably arrives to a perched body through fractures.

\section{Development of the Perched Water Model}

\subsection{Conceptual Model}

Perched water may occur where percolation flux exceeds the capacity of the geologic media to transmit flux in unsaturated zones. At Yucca Mountain, perched water is believed to be a local phenomenon in the unsaturated zone, created by heterogeneity and 
geologic structures within the fractured and unfractured tuffs. Perched water development is also dependent on sufficient recharge from the ground surface. To simulate and predict perched water zones at the site accurately, more site-specific data, such as the quantity and spatial distribution of fracture and matrix properties, formation layering information, and fault properties and distributions, are needed. Detailed modeling studies or predictions of perched water at Yucca Mountain are currently limited by uncertainties in hydrogeological information, observation data at perched water zones, and by the intensive computational requirements of refined 3-D grids.

The conceptual model for perched-water zones in this study is based on the 3-D site-scale unsaturated-zone flow model (Wu et al., 1996b and 1997a) and the associated geological model (Bandurraga, 1996a). The perched water bodies in the area of the North Ramp (near Boreholes UZ-14, SD-9, NRG-7a and G-2, Figure 1) were assumed to lie along the base of the TSw, a zone of altered, more intensely fractured rock. The perched water zones at SD-7 and SD-12 were considered as localized bodies. Lateral water movement in the vicinity of the perched zones was investigated subject to the following assumptions: 1) no large-scale vertically connected fractures transect the underlying lowpermeability units, and 2) both vertical and horizontal permeabilities within the perched water zone are small when compared with measurements outside perching zones.

\subsection{Model Domain and Grid}

The 3-D model domain and grid used in this study are also shown in plan view in Figure 1. The total surface area covered by the model is approximately $43 \mathrm{~km}^{2}$; each horizontal grid layer represents a discretized formation layer using 1,470 irregular integral finite difference gridblocks. The total number of element blocks in the grid is about 40,000 for the ECM model and 80,000 for the dual-permeability model. The grid is designed with increased resolution in the vicinity of the proposed repository, located at the center of the model domain. The model domain (Figure 1) was selected to focus the study at and near the potential repository area and to investigate perched water occurrences near the northern part of the potential repository. All laterally surrounding boundaries are located sufficiently far from the repository so that their effects on simulation results at the repository are small.

Vertically, the layering and subdivision of geological units in the numerical grid are based on the geological model of Bandurraga (1996a). The 3-D model grid has 28 computational grid layers that represent different hydrogeological units or portions of units in the unsaturated zone of Yucca Mountain. From top down, these units are: the Tiva Canyon unit ( $\mathrm{TCw}$ ), vertically subdivided into three layers (may be eroded and not present in some locations), the Paintbrush unit (PTn), represented using five grid layers (similar to the $\mathrm{TCw}$, several layers are eroded and may be missing in certain areas of the model). Below the PTn is the Topopah Spring welded unit (TSw), divided into seven sublayers with three additional computational grid layers used within the potential repository boundary. The Calico Hills $(\mathrm{CHn})$ unit underlies the TSw, and has a 
maximum of eight sublayers, representing vitric or zeolitic facies. However, in order to refine the mesh within the $\mathrm{CHn}$ hydrogeologic unit, two more locally refined layers were added. The bottom boundary of the model is at the water table.

As shown in Figure 1, several major faults are incorporated explicitly in the model, including the Solitario Canyon, Iron Ridge, Ghost Dance/Abandoned Wash, and Dune Wash faults. The Bow Ridge fault is treated as the eastern boundary of the model domain. Based on field evidence indicating that the fault zones are predominantly vertical or near vertical at Yucca Mountain, the faults are represented in the model as vertical zones of finite thickness bounded by sudden stratigraphic offsets in connections to adjacent gridlayers. The scheme used for generating the fault grid elements was outlined by Wittwer et al. (1995).

\subsection{Numerical Code and Modeling Approach}

The simulation results presented were carried out using the TOUGH2 code (Pruess, 1991), a general-purpose reservoir simulator that simulates multi-dimensional coupled fluid and heat flow of multiphase, multi-component fluid mixtures in porous and fractured media. The numerical approach in TOUGH2 is based on the integral finite difference method (Narasimhan and Witherspoon, 1976). The integral finite difference discretization does not make any reference to a global system of coordinates, and thus offers the advantage of being applicable to regular and irregular geometries of gridding in one, two or three dimensions. The method also provides a means of simple preprocessing of geometric data, to implement different methods for treatment of flow in fractured porous media. In the TOUGH 2 formulation, time is discretized fully implicitly using a first-order backward finite difference scheme. The resulting discretized finite difference equations for mass and energy balances are non-linear, and are solved simultaneously using the Newton/Raphson iteration scheme.

The numerical modeling approaches used in this study for treatment of fracture/matrix interflow are (1) the dual-permeability model (Pruess, 1991) and a generalized ECM (Pruess et al., 1990a and 1990b; and Wu et al., 1996a). The dual-permeability approach conceptualizes fractures and matrix as two separate, overlapping continua and treats interactions rigorously. The generalized ECM accommodates two-phase flow in a fracture/matrix system, based on the assumption of local thermodynamic equilibrium between fracture and matrix. Compared to the more rigorous, computationally intensive, dual-permeability model, the ECM generates almost identical results for moisture flow at Yucca Mountain in both 1-D (Doughty and Bodvarsson, 1996, 1997 and this issue) and 3-D (Wu et a., 1996b) simulations under steady-state flow conditions. The ECM, when applicable, provides a substantial simplification in the description of fluid and heat flow in fractured porous media. Favorable conditions for this method are when matrix blocks are relatively small and permeable, and the fracture network is relatively uniformly distributed. The effective-continuum approximation may break down under certain unfavorable conditions, such as during rapid transient flow through tight, large and low 
permeability rock matrix blocks surrounding fractures when a long time to reach local equilibrium under such conditions (Wu and Pruess, 1988).

\subsection{Boundary Conditions and Model Parameters}

The land surface of the mountain (or the tuff/alluvium contact, in areas of significant alluvial cover) is taken as the top model boundary. The water table is treated as the bottom boundary. Both top and bottom boundaries of the models are treated as Dirichlettype conditions, with specified constant (but areally distributed) gas pressures and constant liquid saturation. Constant temperatures used for the boundaries are determined based on field observation (Wu et al., 1996b). Gas pressures for each element of the bottom boundaries are calculated using observed gas pressures corrected to the elevation of boundary block. Surface gas pressures are obtained by running TOUGH2 to steadystate conditions under given temperature and bottom pressure conditions.

A spatially distributed infiltration map (Flint et al., 1996), shown in Figure 2, is used as the top water recharge boundary of the 3-D model, which is added to the second grid layer from top as source terms. This map uses an average net infiltration rate of 4.9 $\mathrm{mm} / \mathrm{yr}$ of water distributed over the site-scale model domain. Areas of higher infiltration are located in the northern part of the model domain and along the south-north ridge of the mountain. Lower infiltration rates dominate in the eastern part of the model domain near the Bow Ridge fault, and near the south-west corner of the model area.

Thermophysical properties of liquid water, air and vapor in the TOUGH2 code are internally generated within experimental accuracy from steam table equations (International Formulation Committee, 1967). Air is treated as an ideal gas and additivity of partial pressures is assumed for air/vapor mixtures.

Properties for rock matrix and fractures were estimated by inverse modeling using the ITOUGH2 code (Finsterle, 1993), based on observed saturation and water potential data from site boreholes. The methodology and procedure of the parameter estimation were discussed by Bandurraga et al. (1996b and 1997); however, permeabilities and capillary pressures for the perched zones were calibrated as discussed below. The rock properties of matrix and fractures used in the ECM model are listed in Table 2. All geological units are treated as fracture/matrix systems, except for the PTn, in which fracture flow effects are ignored.

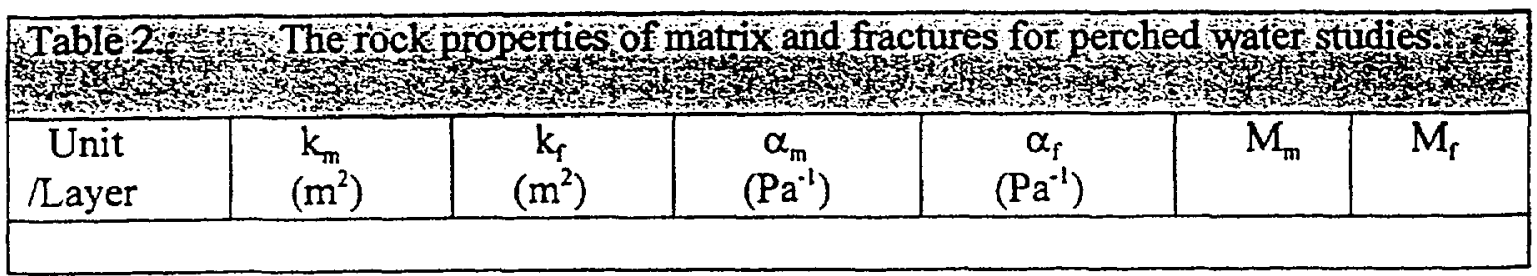




\begin{tabular}{|c|c|c|c|c|c|c|}
\hline \multirow{2}{*}{$\frac{\text { Table 2, }}{\text { tcwl1 }}$} & \multicolumn{6}{|c|}{ The rock properties of matrix and fracfures for perched water studies } \\
\hline & $0.160 \mathrm{E}-18$ & $0.123 \mathrm{E}-10$ & $0.366 \mathrm{E}-05$ & $0.154 \mathrm{E}-03$ & 0.206 & 0.195 \\
\hline tcw12 & $0.963 \mathrm{E}-17$ & $0.575 \mathrm{E}-11$ & $0.126 \mathrm{E}-05$ & $0.123 \mathrm{E}-02$ & 0.250 & 0.231 \\
\hline tcw13 & $0.220 \mathrm{E}-16$ & $0.575 \mathrm{E}-11$ & $0.324 \mathrm{E}-06$ & $0.123 \mathrm{E}-02$ & 0.418 & 0.437 \\
\hline ptn21 & $0.400 \mathrm{E}-12$ & $\mathrm{n} / \mathrm{a}$ & $0.230 \mathrm{E}-04$ & $\mathrm{n} / \mathrm{a}$ & 0.222 & $\mathrm{n} / \mathrm{a}$ \\
\hline $\operatorname{ptn} 22$ & $0.240 \mathrm{E}-12$ & $\mathrm{n} / \mathrm{a}$ & $0.542 E-05$ & $\mathrm{n} / \mathrm{a}$ & 0.310 & $n / a$ \\
\hline $\operatorname{ptn} 23$ & $0.182 \mathrm{E}-12$ & $\mathrm{n} / \mathrm{a}$ & $0.548 \mathrm{E}-04$ & $\mathrm{n} / \mathrm{a}$ & 0.280 & n/a \\
\hline $\mathrm{ptn} 24$ & $0.130 \mathrm{E}-12$ & $\mathrm{n} / \mathrm{a}$ & $0.162 \mathrm{E}-04$ & $n / a$ & 0.370 & $n / a$ \\
\hline $\mathrm{ptn} 25$ & $0.615 \mathrm{E}-12$ & $n / a$ & $0.165 \mathrm{E}-03$ & $\mathrm{n} / \mathrm{a}$ & 0.319 & $n / a$ \\
\hline tsw31 & $0.105 \mathrm{E}-13$ & $0.400 \mathrm{E}-11$ & $0.582 \mathrm{E}-05$ & $0.122 \mathrm{E}-02$ & 0.242 & 0.203 \\
\hline tsw32 & $0.170 \mathrm{E}-15$ & $0.139 \mathrm{E}-10$ & $0.183 \mathrm{E}-04$ & $0.379 \mathrm{E}-04$ & 0.236 & 0.247 \\
\hline tsw33 & $0.200 \mathrm{E}-16$ & $0.710 \mathrm{E}-11$ & $0.656 \mathrm{E}-05$ & $0.202 \mathrm{E}-03$ & 0.248 & 0.238 \\
\hline tsw34 & $0.340 \mathrm{E}-16$ & $0.100 \mathrm{E}-10$ & $0.715 \mathrm{E}-06$ & $0.544 \mathrm{E}-04$ & 0.334 & 0.286 \\
\hline tsw35 & $0.244 \mathrm{E}-15$ & $0.400 \mathrm{E}-11$ & $0.243 \mathrm{E}-05$ & $0.122 \mathrm{E}-02$ & 0.250 & 0.227 \\
\hline tsw36 & $0.382 \mathrm{E}-15$ & $0.400 \mathrm{E}-11$ & $0.571 \mathrm{E}-06$ & $0.122 \mathrm{E}-02$ & 0.418 & 0.416 \\
\hline tsw37 & $0.608 \mathrm{E}-16$ & $0.400 \mathrm{E}-11$ & $0.336 \mathrm{E}-06$ & $0.122 \mathrm{E}-02$ & 0.372 & 0.368 \\
\hline ch1vc & $0.160 \mathrm{E}-11$ & $0.723 \mathrm{E}-12$ & $0.904 \mathrm{E}-04$ & $0.122 \mathrm{E}-02$ & 0.221 & 0.227 \\
\hline $\operatorname{ch} 2 \mathrm{vc}$ & $0.550 \mathrm{E}-13$ & $0.723 \mathrm{E}-12$ & $0.980 \mathrm{E}-04$ & $0.122 \mathrm{E}-02$ & 0.227 & 0.227 \\
\hline $\operatorname{ch} 3 \mathrm{vc}$ & $0.550 \mathrm{E}-13$ & $0.723 \mathrm{E}-12$ & $0.980 \mathrm{E}-04$ & $0.122 \mathrm{E}-02$ & 0.227 & 0.227 \\
\hline ch4vc & $0.550 \mathrm{E}-13$ & $0.723 \mathrm{E}-12$ & $0.980 \mathrm{E}-04$ & $0.122 \mathrm{E}-02$ & 0.227 & 0.227 \\
\hline chlzc & $0.540 \mathrm{E}-15$ & $0.100 \mathrm{E}-12$ & $0.190 \mathrm{E}-06$ & $0.730 \mathrm{E}-03$ & 0.359 & 0.359 \\
\hline $\operatorname{ch} 2 \mathrm{zc}$ & $0.450 \mathrm{E}-17$ & $0.100 \mathrm{E}-12$ & $0.421 \mathrm{E}-05$ & $0.516 \mathrm{E}-03$ & 0.228 & 0.225 \\
\hline ch3zc & $0.450 \mathrm{E}-17$ & $0.100 \mathrm{E}-12$ & $0.421 \mathrm{E}-05$ & $0.516 \mathrm{E}-03$ & 0.228 & 0.225 \\
\hline $\operatorname{ch} 4 \mathrm{zc}$ & $0.840 \mathrm{E}-17$ & $0.100 \mathrm{E}-12$ & $0.150 \mathrm{E}-06$ & $0.730 \mathrm{E}-03$ & 0.476 & 0.476 \\
\hline $\mathrm{pp} 3 \mathrm{vp}$ & $0.602 \mathrm{E}-15$ & $0.300 \mathrm{E}-13$ & $0.203 \mathrm{E}-04$ & $0.122 \mathrm{E}-02$ & 0.347 & 0.313 \\
\hline $\mathrm{pp} 2 \mathrm{zp}$ & $0.170 \mathrm{E}-16$ & $0.100 \mathrm{E}-12$ & $0.179 \mathrm{E}-05$ & $0.730 \mathrm{E}-03$ & 0.312 & 0.312 \\
\hline bf3vb & $0.602 \mathrm{E}-15$ & $0.300 \mathrm{E}-13$ & $0.203 \mathrm{E}-04$ & $0.122 \mathrm{E}-02$ & 0.347 & 0.313 \\
\hline $\mathrm{bf} 2 \mathrm{zb}$ & $0.170 \mathrm{E}-16$ & $0.100 \mathrm{E}-12$ & $0.179 \mathrm{E}-05$ & $0.730 \mathrm{E}-03$ & 0.312 & 0.312 \\
\hline $\operatorname{tm} 3 \mathrm{vt}$ & $0.602 \mathrm{E}-15$ & $0.300 \mathrm{E}-13$ & $0.203 \mathrm{E}-04$ & $0.122 \mathrm{E}-02$ & 0.347 & 0.313 \\
\hline
\end{tabular}

In Table $2, k_{m}$ and $k_{f}$ are saturated matrix and fracture continuum permeabilities; $\alpha_{m}$ and $\alpha_{f}$ are van Genuchten's parameters (van Genuchten, 1980) of capillary pressure of matrix and fracture, respectively; and $m_{m}$ and $m_{f}$ are van Genuchten's parameters of relative permeabilities.

Uniform fault properties (Wu et al., 1997b) were specified for all the explicitly incorporated faults, as shown in Figure 1. A matrix permeability of $100 \mathrm{md}$ was used for faults, and horizontal and vertical permeabilities for fractures within fault zones were taken as 10 and $100 \mathrm{~d}$, respectively. For fault zones, $\alpha_{\mathrm{m}}=0.61 \mathrm{E}-4\left(\mathrm{~Pa}^{-1}\right), \alpha_{\mathrm{f}}=1.0 \mathrm{E}-3$ $\left(\mathrm{Pa}^{-1}\right), \quad \mathrm{m}_{\mathrm{m}}=0.5$, and $\mathrm{m}_{\mathrm{f}}=0.5$. 


\section{Results and Analyses}

\subsection{Model Representation of Perched Water Bodies}

The basic feature of a perched water body is that there exists a high water content or saturation region in a vadose zone, and the porous and fractured rock within this zone is fully or almost fully saturated. Substantial fracture flow may be initiated if a perching zone is in a fractured unit. The capillary forces, or water potentials, become very small, or even positive under fully saturated conditions. Water perching conditions may also be established under certain two-phase conditions when there exists a residual or trapped gas saturation. In this case, the system may never become completely liquid saturated, and the local capillary pressures, or pressure heads, are always negative. However, as liquid content builds up and the air phase becomes trapped, isolated, and immobile, both water and gas pressures increase locally. Once the local water pressure reaches a threshold value, such as the static atmospheric gas pressure at the location if no perched water exists, water will seep out from the fractures or pores if a borehole or tunnel intersects this zone. From a modeling point of view, a perched water zone may be established when water saturation is high enough and capillarity is sufficiently small, and a sufficient condition of water perching is that there exists a positive pressure head.

In our 3-D model, each borehole intersecting a perched water zone was represented using the corresponding rock columns from the 3-D site-scale model grid. The 3-D simulation results were analyzed in terms of saturation and water potential profiles to facilitate direction comparisons with measured data. Also, 3-D model results were displayed using two 2-D vertical cross-sections. The locations of the two cross-sections are shown in Figure 1. Cross-section E-E' is a south-north cross-section, crossing SD-7, SD-12 and SD-9, NRG-7a and G-2, and the west-east cross-section, C-C', intersects UZ-14.

\subsection{Comparisons with Observed Borehole Data}

As a first step for perched water calibrations of the flow model, observed saturations and perched water locations were compared with the dual-permeability model predictions. Figures 3 to 8 show comparisons of the simulated and observed saturation profiles and perching locations for Boreholes UZ-14, NRG-7a, SD-7, SD-9, SD-12 and G-2. As shown in these figures, the observed saturation and water potential values are selected from available measured data (OCRWM/DOE, 1995). The simulation results are generally in good agreement with both measured saturation profiles and water perching locations of these boreholes.

Figure 3 shows comparisons of the simulated and observed saturations for Borehole UZ14, indicating a reasonable agreement. An especially good correlation exists for saturations at all depths. At the perched water location of about $960 \mathrm{~m}$ elevation, the 
simulation results show that water saturation is 1 , and water pressure is greater than atmospheric pressure at the location. This implies that perched-water conditions are created in this case by the model, and also that the simulated results match the perched water elevation as shown in the figure.

Figure 4 shows the simulation results for the NRG-7a borehole, indicating that the simulated water saturation profile matches the observed profile in the upper part of the borehole data, but is not in very good agreement with the observed values in the lower portion. The simulated saturation profile is a little "wetter" than observed data in the lower part of the TSw unit. This may be due to the quality of the measured data, because the sample cores taken from the borehole were not handled properly, and some moisture may have been lost (Flint, 1996). The predicted perched water elevation agrees well with the observation.

Figures 5, 6, 7 give the results for Boreholes SD-7, SD-9, and SD-12. The comparisons of the simulated and observed saturations and perching locations are all reasonable. For all the three cases, the perched water locations are reproduced well by the 3-D model. Fully saturated condition and zero water potentials are obtained in the simulation results at the perched water levels for these boreholes. Figure 8 shows only the simulation results for Borehole G-2, because no measurements for Borehole G-2 are available. The comparisons of the simulated and observed perched water locations are in good agreement. There is a very thick zeolitic layer at this location, from the base of TSw to the water table, and a very thick $(\sim 100 \mathrm{~m})$ perched water zone is predicted by the model.

In order to calibrate the 3-D, UZ site-scale model against observed perched waterconditions at Yucca Mountain, some local modification of rock properties was required. In general, permeability was adjusted only within the model layers associated with the perching zone. Conceptually, in order for perched water to form, either a capillary and/or a permeability barrier condition must exist. For example, when a fine-grained material overlies a coarse grained material, a capillary barrier exists that prevents water from entering the coarse grained material, because the capillary pressure gradient between the two grid layers tends to move water upward. On the other hand, a permeability barrier exists where higher permeability material overlies a lower permeability material. In this case, the percolation flux from the high permeability zone may be higher than the transmission capacity of the underlying material, and water accumulation or lateral diversion will occur.

At Yucca Mountain, a common example of perching due to a permeability barrier is where the highly fractured basal vitrophyre of the TSw unit overlies the underlying bedded units. In addition to a capillary or permeability barrier, two other conditions are required for perched water to exist: certain lateral confinement and sufficient percolation flux. Water diverted laterally may be confined due to an offsetting bed, mineralization, fault gouge, or capillary barrier effects associated with a fault or laterally confining permeability. In this study, fracture and matrix permeabilities were both reduced to investigate how low vertical and lateral confinement must be to generate perched water 
under various infiltration scenarios. This change is consistent with evidence that suggests that fracture walls can be altered to low permeability minerals which then block flow through fractures (Rousseau et al., 1996) and that fracture connectivity and density varies drastically at geologic units with perched water (Borger and Scofield, 1994). Nevertheless, all the adjusted matrix permeabilities made in this study were within the ranges of observed and/or laboratory measured values.

For the perched water zone connecting and surrounding Boreholes UZ-14, SD-9, NRG$7 \mathrm{a}$, and G-2, fracture and matrix rock properties in grid layers, tsw37, ch1zc, and ch $2 \mathrm{zc}$ were adjusted and renamed as $p \operatorname{ch} 37, p \operatorname{ch} 1 z$ and $p \operatorname{ch} 2 z$. The layers corresponding to the bottom of the TSw and the two upper layers of the $\mathrm{CHn}$, respectively. To calibrate against the perched water body at SD-7, model layers ch3zc and ch4zc were adjusted, and at SD-12, model layers ch2vc, ch3zc and ch4zc were adjusted. These layers were renamed as pch $2 z, p c h 3 z$ and pch $4 z$, respectively. Table 3 shows the adjusted rock parameters used in the model.

\begin{tabular}{|c|c|c|c|c|c|c|c|c|}
\hline Units & $\begin{array}{l}k_{\mathrm{m}} \\
\left(\mathrm{m}^{2}\right)\end{array}$ & $\begin{array}{l}k_{\mathrm{f}} \\
\left(\mathrm{m}^{2}\right)\end{array}$ & $\begin{array}{l}\alpha_{\mathrm{m}} \\
\left(\mathrm{Pa}^{-1}\right)\end{array}$ & $\begin{array}{l}\alpha_{\mathrm{f}} \\
\left(\mathrm{Pa}^{-1}\right)\end{array}$ & $\mathrm{m}_{\mathrm{m}}$ & $\mathrm{m}_{\mathrm{f}}$ & $\overline{S_{\mathrm{gr}}}$ & $\mathrm{S}_{1 \mathrm{~s}}$ \\
\hline & & & & & & $72+2>$ & 007 & \\
\hline$\frac{\text { pens/1 }}{\text { nchiz }}$ & $0.008 \mathrm{E}-1 /$ & $0.304 \mathrm{E}-17$ & $0.350 \mathrm{E}-0$ & $0.350 E-0$ & 0.312 & $\frac{362}{250}$ & 0.02 & 1.0 \\
\hline peniz & $0.540 \mathrm{E}-17$ & $0.120 \mathrm{E}-16$ & $0.190 \mathrm{E}-6$ & $0.190 \mathrm{E}-6$ & 0.359 & 0.559 & 0.02 & 1.0 \\
\hline $\mathrm{pch} 2 \mathrm{z}$ & $0.450 \mathrm{E}-18$ & $0.350 \mathrm{E}-17$ & $0.421 \mathrm{E}-5$ & $0.421 \mathrm{E}-5$ & 0.228 & 0.228 & 0.02 & 1.0 \\
\hline pch3z & $0.450 \mathrm{E}-17$ & $0.450 \mathrm{E}-17$ & $0.421 \mathrm{E}-5$ & $0.421 \mathrm{E}-5$ & 0.228 & 0.228 & 0.01 & 0.98 \\
\hline pch $4 z$ & $0.840 \mathrm{E}-17$ & $0.840 \mathrm{E}-17$ & $0.150 \mathrm{E}-6$ & $0.150 \mathrm{E}-6$ & 0.476 & 0.476 & 0.01 & 0.98 \\
\hline
\end{tabular}

In Table 3, $\mathrm{S}_{\mathrm{gr}}$ is residual gas saturation; and $\mathrm{S}_{\mathrm{ls}}$ is satiated liquid saturation. As shown in Table 3, the other important modification to the rock properties in the perched water zone is the introduction of residual gas and satiated saturation mechanisms to account for the trapped air phenomena in the rock matrix. Under such conditions, gas phase becomes immobile and capillary pressure reduces to very small or zero for gas saturation below its residual value.

\subsection{Simulated Perched water Bodies}

Figures 3 to 8 show only the observed and simulated perched water elevations vertically. Simulated perched water bodies and their extensions will be discussed using 2-D and 3-D plots. The 2-D plots display results extracted from outputs from 3-D dual-permeability simulations. 
Figure 9 is a plan view of a 3-D plot, showing water saturation contours along the top of the $\mathrm{CHn}$ zeolitic unit, at an elevation of $900 \mathrm{~m}$. It clearly indicates that an extensive perched water body in the northern part of the model domain, which surrounds Boreholes UZ-14, SD-9, NRG-7a, and G-2. Figure 9 also shows very low saturations along the major faults, because of higher permeability and low capillary suction forces in the fault zones.

Vertical profiles of the perched water bodies can be seen from the two vertical crosssections (Figure 1). Figure 10 shows the water saturation distributions along the southnorth (E-E') cross section. As displayed on this figure, an extensive water body exists along the north-south direction from G-2. The simulated perched water body agrees with the observed perched water locations at SD-7, SD-12, SD-9 and G-2 in the cross-section, as indicated on the figure. However, the perched water bodies for SD-7 and SD-12 are small, and not hydraulically connected.

Along the west-east cross-section ( $C-C^{\prime}$ ), shown in Figure 1, the simulated perched water profiles are also in good agreement with the observed perched water elevations from Borehole UZ-14. The figure shows a lower, vertical saturation zone along the Salitario Canyon Fault, west to UZ-14.

\section{Pumping Test Analysis}

Several hydraulic pumping tests have been conducted (Soeder, 1995; Luckey, 1993; O'Brien, 1996) to study perched water occurrences at several perched water boreholes. Some of these tests have provided useful information on the physical characteristics (water volume, local formation transmissivity) of the perched water, including the tests from UZ-14 and G-2. In this section, numerical pumping test analyses were conducted using one UZ-14 pumping test and one pumping test from G-2, and the 3-D ECM model results in order to calibrate the model for perched water bodies.

\subsection{Pumping Tests of UZ-14}

According to Luckey (1993), four hydraulic pumping tests were conducted in UZ-14 between August 17-27, 1993, and two of the four tests (test 2 and 4) were successful. We selected test 2 for our analysis using the 3-D model. As summarized in Section 2, the perched water body in UZ-14 was encountered at a depth of $383 \mathrm{~m}$, in the lower nonlithophysal unit of Topopah Spring. The static fluid level was at a depth of $1,250 \mathrm{ft}$ or $381 \mathrm{~m}$, or at an elevation of $968 \mathrm{~m}$. In test 2, which was conducted on August 19, 1993, water was pumped from the borehole at a rate of $0.90 \mathrm{gal} / \mathrm{min}$ for 13 hours, and then pumping was stopped. The water level was continuously monitored for 20 more hours. The total pumpage was 6,190 gallons, and total pumping time was 102.2 hours in the 4 tests. The water level at the borehole fully recovered in about 5.6 days after the tests were stopped. 
In order to analyze the pumping tests using the 3-D site-scale numerical model with a spatially discretized grid, the mesh size must be fine enough to obtain acceptable resolutions in the calculated pressures at the borehole. A locally refined, R-Z mesh was generated and embedded into the perched water layer at UZ-14 (tsw37 or pch37). The locally refined, embedded R-Z grid was centered at UZ-14 with a borehole of radius 12 $1 / 4$ inches.

Many numerical simulations were conducted to understand the hydraulic responses of the perched water body, and to match the pumping test results. Several calibrations to the refined R-Z meshes and their properties were carried out to fit both water drawdown and recovery data. The calibrated parameters include the minimum volume of the perched water body and the local horizontal permeability around boreholes. The local horizontal permeability represents local fractures that connect with boreholes and provide pathways for water flow to the borehole on a much smaller scale of 0.1 to 1 meters. Also, these calibrated horizontal permeabilities do not contribute to global vertical flow crossing through the entire perched water grid layers at the spatial scale used in the 3-D site-scale model grid $(>10 \mathrm{~m})$. The calibrated results are: (1) the formation volume of a perched water zone is at least at $5.0 \times 10^{7} \mathrm{~m}^{3}$; and (2) the perched water zone near UZ-14 can be represented by a radially composite formation with two different local horizontal permeabilities of ( $k=250 \mathrm{md}$ for $\mathrm{R}<150 \mathrm{~m}$, and $\mathrm{k}=150 \mathrm{md}$ for $\mathrm{R}>150 \mathrm{~m}$ ).

The comparison of the observed and simulated pumping test results for UZ-14 is shown in Figure 12 for pumping test 2. Figure 12 indicates that there is excellent agreement between the observed and simulated water level depth at a function of observation times, and the model-predicted water levels not only match the drawdown period of pumping, but also the entire recovery (or buildup) period after pumping stopped. This indicates that both the perched water condition created by the 3-D model and the adjustments in the local horizontal permeability near the borehole are reasonable.

\subsection{Pumping Test of G-2}

A recent pumping test at Borehole G-2 (O'Brien, 1996) was conducted on G-2 from April $8-25,1996$, with pumping for 17 days. The recovery period lasted from April 25, 1996 to December 1996, for more than 236 days. For the pumping period, water was pumped from the borehole at an average rate of $57 \mathrm{gal} / \mathrm{min}$ for 17 days, and then pumping stopped. The water level was continuously monitored for 236 more days, after which and there was still about 0.5 meters of residual drawdown in this borehole.

The pumping test analysis procedure for G-2 is similar to that used for UZ-14, i.e., a locally refined R-Z mesh is embedded in the 3-D model and is connected to the perched water body in G-2. Next, a series of numerical pumping tests were conducted to compare the simulated hydraulic responses of the perched water body with observed water 
drawdown and recovery data. The calibrated parameters include minimum formation volume of perched water body, porosity, and local horizontal permeability. The calibrated results are: (1) the formation volume of the perched water zone is on the order of $1.0 \times 10^{9} \mathrm{~m}^{3}$; and (2) the perched water zone near G-2 is a radially composite formation with two different local horizontal permeabilities $(k=1 \mathrm{~d}$ for $\mathrm{R}<40 \mathrm{~m}$, and $\mathrm{k}=350 \mathrm{md}$ for $\mathrm{R}>40 \mathrm{~m}$ ).

Figure 13 shows the comparisons of the observed and simulated pumping test results for G-2. The plot indicates that there is an excellent agreement between the observed and simulated water level depth versus observation times. The model predicted water levels not only match the drawdown period of pumping, but these levels also match the over 200 day recovery period.

\section{Concluding Remarks}

This paper presents an example of the application of a numerical model to the study of perched water occurrences in the vadose zone. The modeling analysis was based on a field investigation of perched water at Yucca Mountain. The presence of perched water at Yucca Mountain has many implications for the hydraulic system, and also may provide useful information to improve our understanding of fluid flow through the mountain. The occurrence of perched water bodies in the unsaturated zone of Yucca Mountain indicates that there exist water-trapping conditions in these formations. It also implies that much higher infiltration rates may have existed in the past, and that there may exist preferential pathways for water to travel from the surface to water table. Water that is retarded and diverted by perched zones may flow laterally through fault zones or other high permeability channels, bypassing the low permeability zeolitic units in the CHn. As a result, very non-uniform recharge is expected at the water table.

A 3-D UZ flow model was developed to investigate perched water phenomena at Yucca Mountain. Perched water data from 6 boreholes were used to calibrate matrix and fracture properties for the 3-D, steady-state model using an areally distributed infiltration map. The steady-state results of this modeling study were in agreement with the observed perched water data, in terms of water saturation and perched water locations. Additionally, a transient numerical pumping test was performed using a 3-D submodel for two boreholes. The numerical pumping test results match well with the observed water level data from pumping to recovery period.

The modeling study and sensitivity analysis of this work indicate that there are several key factors in creating a perched-water zone using a numerical reservoir simulator. These factors are (1) a water perching geologic structure with low permeability zones and/or a capillary barrier underlain and surrounding, (2) weak capillary forces under high 
saturation condition within and near perched-water zones, and (3) sufficient water infiltration rates.

\section{Acknowledgment}

The authors are grateful to R. W. Zimmerman, J. Fairley, H. H. Liu and K. Huang for their careful review of this paper. This work was supported by the Director, Office of Civilian Radioactive Waste Management, U. S. Department of Energy, through Memorandum Purchase Order EA9013MC5X between TRW Environmental Safety Systems Inc. and the Ernest Orlando Lawrence National Laboratory. The support is provided to Lawrence Berkeley National Laboratory through the U. S. Department of Energy Contract No. DE-AC03-76SF00098.

\section{References}

Bandurraga, T. M. and G. S. Bodvarsson, Calibrating Matrix and Fracture Properties Using Inverse Modeling, Chapter 6 of "The Site-Scale Unsaturated Zone Model of Yucca Mountain, Nevada, for the Viability Assessment" Edited by G. S. Bodvarsson, M. Bandurraga and Y. S. Wu, Yucca Mountain Site Characterization Project Report, LBNL40376, UC-814, Lawrence Berkeley National Laboratory, Berkeley, CA, 1997.

Bandurraga, T.M. Geological model development and vertical layering scheme for the numerical grid, Chapter 2 of "Development and calibration of the three-dimensional sitescale unsaturated-zone model of Yucca Mountain, Nevada" Edited by G. S. Bodvarsson and M. Bandurraga, Yucca Mountain Site Characterization Project Report, Lawrence Berkeley National Laboratory, Berkeley, CA, 1996a.

Bandurraga, T.M., S. Finsterle, and G.S. Bodvarsson, Saturation and capillary pressure analysis, Chapter 3 of "Development and calibration of the three-dimensional site-scale unsaturated-zone model of Yucca Mountain, Nevada" Edited by G. S. Bodvarsson and M. Bandurraga, Yucca Mountain Site Characterization Project Report, Lawrence Berkeley National Laboratory, Berkeley, CA, $1996 \mathrm{~b}$.

Burger, P.A. and Scofield, K.M., Perched water at Yucca Mountain -- implications on the exploratory studies facility, Nye County, Nevada, Water-Resources Investigations Report, U.S. Geological Survey, 1994.

Craig, R. W., "Transmittal of Deliverable 3GRG103M-Letter Report: Hydrogeology of Borehole USW G-2", Letter to Susan Jones (DOE), USGS, 1995.

Czarnecki, J., Personal Communication, 1995.

Doughty, C., and G. S. Bodvarsson, 1996. Investigation of Conceptual and Numerical approaches for Evaluating Moisture, Gas, Chemical, and Heat Transport in Fractured 
Doughty, C., and G. S. Bodvarsson, 1996. Investigation of Conceptual and Numerical approaches for Evaluating Moisture Flow and Chemical Transport, Chapter 5 of "The Site-Scale Unsaturated Zone Model of Yucca Mountain, Nevada, for the Viability Assessment" Edited by G. S. Bodvarsson, M. Bandurraga and Y. S. Wu, Yucca Mountain Site Characterization Project Report, LBNL-40376, UC-814, Lawrence Berkeley National Laboratory, Berkeley, CA, 1997.

Doughty, C. and G.S. Bodvarsson, Investigation of conceptual and numerical approaches for evaluating gas, moisture, heat flow and chemical transport, Chapter 6 of "Development and calibration of the three-dimensional site-scale unsaturated-zone model of Yucca Mountain, Nevada" Edited by G. S. Bodvarsson and M. Bandurraga, Yucca Mountain Site Characterization Project Report, Lawrence Berkeley National Laboratory, Berkeley, CA, 1996.

EG \& G Energy Measurements, Remote Sensing Laboratory, Yucca Mountain site characterization project, site atlas, 1994.

Fabryka-Martin J.T., P.R. Dixon, S. Levy, B. Liu, H.J. Turin, and A.V. Wolfsburg, Summary Report of ${ }^{36} \mathrm{Cl}$ Studies: Systematic Sampling for ${ }^{36} \mathrm{Cl}$ in the Exploratory Studies Facility, Los Alamos National Laboratory Milestone Report 3783AD (Level 4), Los Alamos National Laboratory, Los Alamos, NM, 1996.

Finsterle, S., ITOUGH2 User's Guide, Version2.2, Research Report LBL-34581, UC600, August, 1993.

Flint, L., Personal communication, 1996.

Flint, A. L., Hevesi, J. A. and Flint, E. L., Conceptual and Numerical Model of infiltration for the Yucca Mountain Area, Nevada, U. S. Geological Survey, WaterResources Investigation Report-96, Denver, Colorado, 1996.

Freeze, R. A., and Cherry, J. A., Groundwater, Englewood Cliffs, N. J., Prentice-Hall, 1979.

Forsyth, P. A., Y. S. Wu, and K. Pruess, Robust Numerical Methods for SaturatedUnsaturated Flow with Dry Initial Conditions in Heterogeneous Media, Advances in Water Resources, Vol. 18, pp. 25-38, 1995.

Geslin, J., T. Moyer, and D. C. Buesch, Summary Of Lithologic Logging Of New And Existing Boreholes At Yucca Mountain, Nevada, August 1993 to February 1994, U.S. Geological Survey Open-File Report 94-342, NRG-7a, UZ-14, UZ\#16, 1994. 
Hevesi, J. A. and Flint, A. L., Geostatistical Model for Estimating Precipitation and Recharge in the Yucca Mountain Region, Nevada-California, U. S. Geological Survey, Water-Resources Investigation Report, Denver, Colorado, 1995.

Hinds, J. J., C. J. Fridrich, and S. Ge, Numerical Modeling of Perched Water under Yucca Mountain, Nevada, In press, 1997.

Hoxie, D. T., A Conceptual Model for the Unsaturated-Zone Hydrogeologic System, Yucca Mountain, Nevada, Radioactive Waste Management and the Nuclear Fuel Cycle, Vol. 13 (1-4), pp. 63-75, 1989.

International Formulation Committee, A Formulation of the Thermodynamic Properties of Ordinary Water Substance, IFC Secretariat, Düsseldorf, Germany, 1967.

Kirkland, M. R., R. G. Hills, and P. J. Wieranga, Algorithms for Solving Richards' Equation for Variably Saturated Soils, , Water Resources Res., 28, pp.2049-2058, 1992.

Luckey, R. R., Update on Fluid in USW UZ-14, Presented in the Nuclear Waste Technical Review Board Meeting, Las Vegas, Nevada, 1993.

Moldonado, F. and Koether, S. L., Stratigraphy, structure and Some Petrographic Features of Tertiary Volcanic Rock at the USW G-2 Drill Hole, Yucca Mountain, Nye County, Nevada, U. S. geological survey Open File Report 83-732, 1983.

Narasimhan, T.N., and Witherspoon, P.A., An Integrated Finite Difference Method for Analyzing Fluid Flow in Porous Media, Water Resources Research, 12(I), pp. 57-64, 1976.

O'Brien, G., Data Summary Sheet, Water-level and Related Data Collected during Aquifer Tests conducted in Borehole USW G-2, April 8 to December 17, Draft Report, U. S. Geological Survey, 1996.

OCRWM, DOE, Technical Data Catalog, Yucca Mountain Site Characterization Project, 1995.

Patterson, G., Identification of Water-Flow Pathways: Perched Water Occurrences, U. S.G.S., Written Material Presented at Unsaturated Zone Flow Model Expert Elicitation Project Workshop I, Lawrence Berkeley National Laboratory, Berkeley, CA, 1996.

Pruess, K., TOUGH2 -- a general-purpose numerical simulator for multiphase fluid and heat flow, Report No. LBL-29400, Lawrence Berkeley Laboratory, Berkeley, CA, 1991.

Pruess, K., J.S.Y. Wang, and Y.W. Tsang, On thermohydrologic conditions near high level nuclear wastes emplaced in partially saturated fractured tuff, part I. simulation studies with explicit consideration of fracture effects, Water Resources Res., 26(6), 12351248,1990 a. 
Pruess, K., J.S.Y. Wang, and Y.W. Tsang, On the thermohydrologic conditions near high-level nuclear wastes emplaced in partially saturated fractured tuff, part 2. Effective continuum approximation, Water Resources Res., 26(6), 1249-1261,1990b.

Rautman, R.A. and Engstrom, D. A., Geology Of The USW SD-7 Drill Hole, Yucca Mountain, Nevada, Sandia National Laboratory Letter Report SLTR-96-000X., SNL Report SAND96-1474, 1996a.

Sonnenthal et al., Modeling the geochemistry in the unsaturated zone, this issue.

Rautman, R. A. and Engstrom, D.A., Geology Of The USW SD-12 Drill Hole, Yucca Mountain, Nevada, Sandia National Laboratory Letter Report SLTR-96000X, MOL.19961219.0271, N/A, SNL Report SAND96-1368, $1996 \mathrm{~b}$.

Rousseau, J.P., E.M. Kwicklis, and C. Gillies, Dds, Hydrogeology of the unsaturated zone, North Ramp area of the Exploratory Studies Facility, Yucca Mountain, Nevada, U.S. Geological Survey, Water-Resources Investigations 96-xxxx, 1996 (in print).

Soeder, D., Personal Communication, 1995.

Striffler, P., G.M. O'Brien, T. Oliver, and P. Burger, Perched water characteristics and occurrences, Yucca Mountain, Nevada, U. S. Geological Survey, Dencer, Colorado, 1996.

van Genuchten. M., A closed form solution for predicting the properties the hydraulic conductivity of unsaturated soils, Soil. Sci. Soc. Am. J., 44, pp. 892-898, 1980.

Wittwer, C., G. Chen, G.S. Bodvarsson, M.P. Chornack, A.L. Flint, L.E. Flint, E. Kwicklis, and R.W. Spengler, Preliminary development of the LBL/USGS threedimensional site-scale model of Yucca Mountain, Nevada, Report LBL-37356, UC-814, Lawrence Berkeley National Laboratory, Berkeley, CA, 1995.

Wu, Y. S., A. C. Ritcey, C. Haukwa, and G.S. Bodvarsson, Integrated 3-D Site-Scale Flow Model, Chapter 19 of "The Site-Scale Unsaturated Zone Model of Yucca Mountain, Nevada, for the Viability Assessment" Edited by G. S. Bodvarsson, M. Bandurraga and Y. S. Wu, Yucca Mountain Site Characterization Project Report, LBNL-40376, UC-814, Lawrence Berkeley National Laboratory, Berkeley, CA, 1997a.

Wu, Y.S., A.C. Ritcey, E.L. Sonnenthal, T.M. Bandurraga, C. Haukwa, J.P. Fairley, G. Chen, J.H. Li, and G.S. Bodvarsson, Incorporation of Perched Water Data into the UZ Site-Scale Model, Yucca Project Milestone SP24UCM4, Lawrence Berkeley National Laboratory, Berkeley, CA, 1997b.

Wu, Y.S., S. Finsterle, and K. Pruess, Computer Models and their development for the unsaturated zone model at Yucca Mountain, Chapter 4 of "Development and calibration 
of the three-dimensional site-scale unsaturated-zone model of Yucca Mountain, Nevada" Edited by G. S. Bodvarsson and M. Bandurraga, Yucca Mountain Site Characterization Project Report, Lawrence Berkeley National Laboratory, Berkeley, CA, 1996.

Wu, Y.S., G. Chen, C. Haukwa, and G.S. Bodvarsson, Three-dimensional model calibration and sensitivity studie, Chapter 8 of "Development and calibration of the threedimensional site-scale unsaturated-zone model of Yucca Mountain, Nevada" Edited by G. S. Bodvarsson and M. Bandurraga, Yucca Mountain Site Characterization Project Report, Lawrence Berkeley National Laboratory, Berkeley, CA, $1996 \mathrm{~b}$.

Wu, Y.S., G. Chen, and G.S. Bodvarsson, Preliminary analysis of effects of thermal loading on gas and heat flow within the framework of the LBNL/USGS site-scale model, Research Report LBL-37229, UC-814, Lawrence Berkeley National Laboratory, Berkeley, CA, 1995.

Wu, Y.S. and K. Pruess, A multiple-porosity method for simulation of naturally fractured petroleum reserviors, SPE Reservoir Engineering, 3, pp.327-336, 1988

Yang, I. C., G.W. Rattray, and P. Yu, Interpretations Of Chemical And Isotopic Data From Boreholes In The Unsaturated-Zone At Yucca Mountain, Nevada, U. S. Geological SurveyWater-ResourcesInvestigationReport-96-4058, N/A, GS970108312271.001, U. S. Geological Survey, Denver, Colorado, 1996. 


\section{Figure Captions:}

Figure 1 Locations of boreholes with perched water occurrences and a plan view of site-scale model domain, showing model boundary, grid, and major faults.

Figure 2 Net infiltration map showing the distribution of net infiltration over Yucca Mountain (modified from Flint et al., 1996).

Figure 3 Comparisons of the simulated and observed saturations and perched water locations for Borehole UZ-14.

Figure 4 Comparisons of the simulated and observed saturations and perched water locations for Borehole NRG-7a.

Figure 5 Comparisons of the simulated and observed saturations and perched water locations for Borehole SD-7.

Figure 6 Comparisons of the simulated and observed saturations and perched water locations for Borehole SD-9.

Figure 7 Comparisons of the simulated and observed saturations and perched water locations for Borehole UZ-12.

Figure 8 Comparisons of the simulated saturations and observed perched water locations for Borehole G-2.

Figure 9 A plan view of 3-D saturation contours showing the perched water body surrounding UZ-1/14, SD-9, NRG-7a, and G-2.

Figure 10 Vertical saturation contours along south-north cross-section (E-E) through SD-7, SD-12, SD-9 and G-2 perched water zones.

Figure 11 Vertical saturation contours along west-east cross-section (E-E') through the UZ-1/14 water zone.

Figure 12 Comparison of the observed and simulated water level drawdown and recovery of Pumping Test 2 of UZ-14.

Figure 13 Comparison of the observed and simulated water level drawdown and recovery of pumping of $\mathrm{G}-2$. 


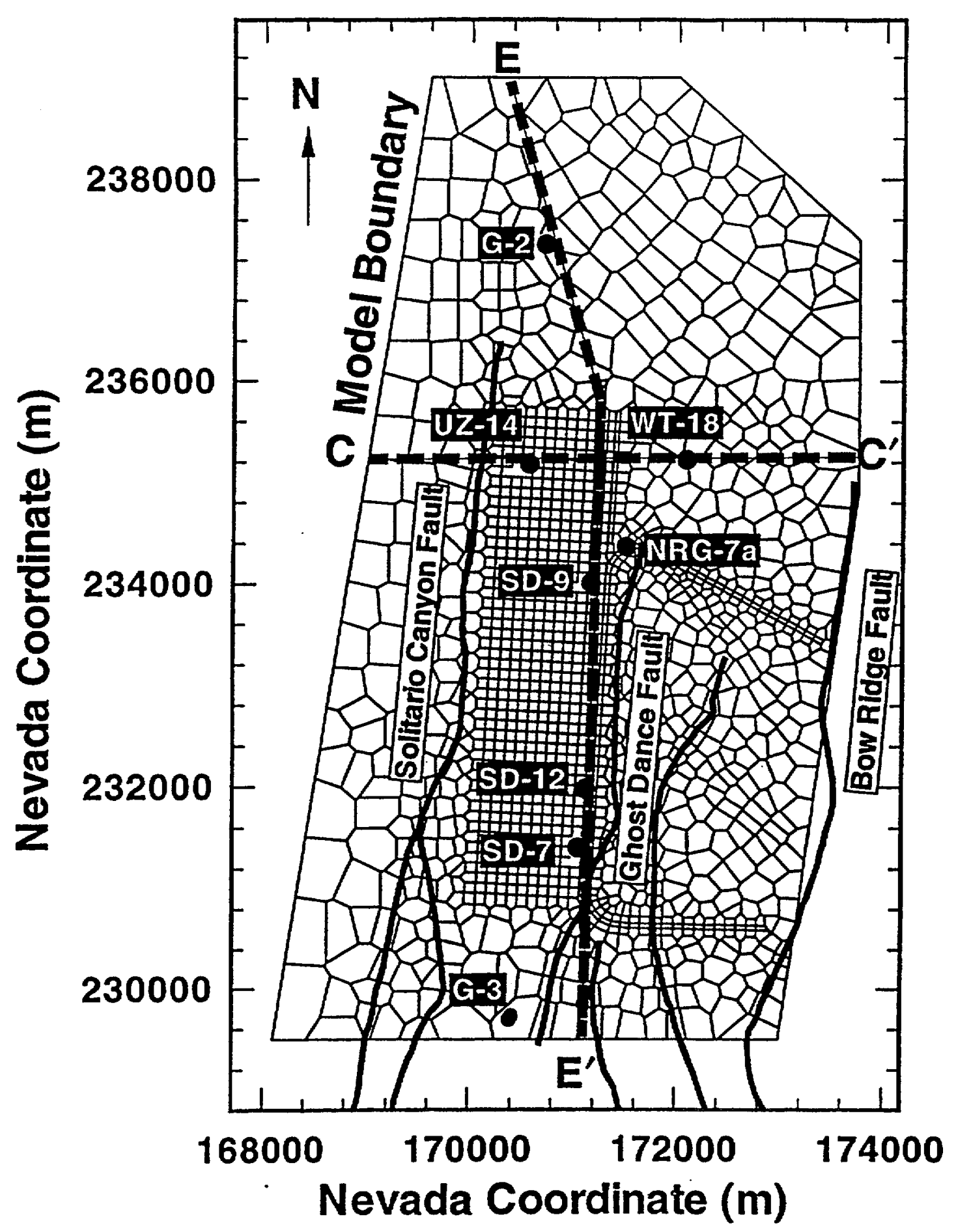

Figure 1 Locations of boreholes with perched water occurrences and a plan view of site-scale model domain, showing model boundary, grid, and major faults. 


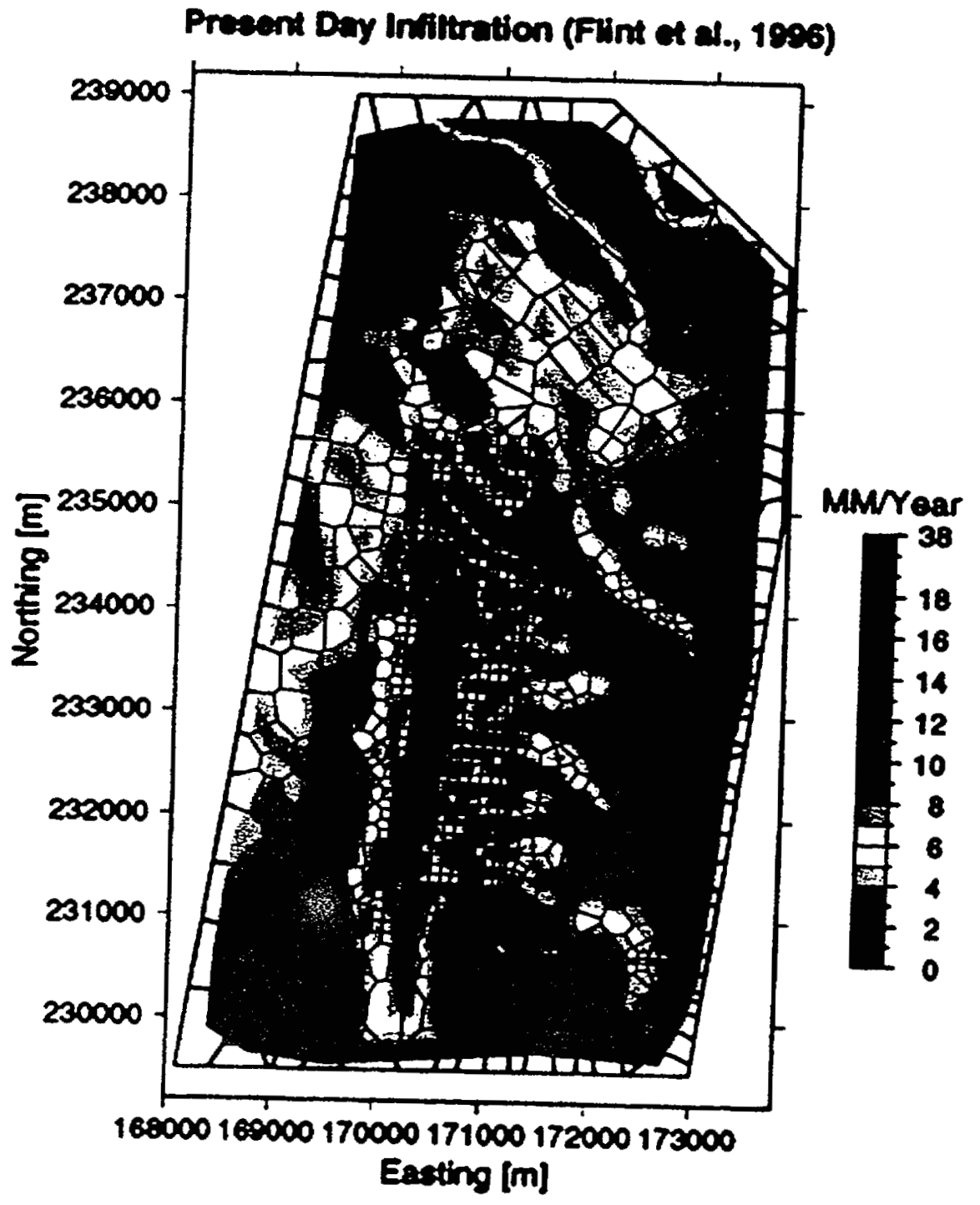

Figure 2 Net infiltration map showing the distribution of net infiltration over Yucca Mountain (modified from Flint et al., 1996). 


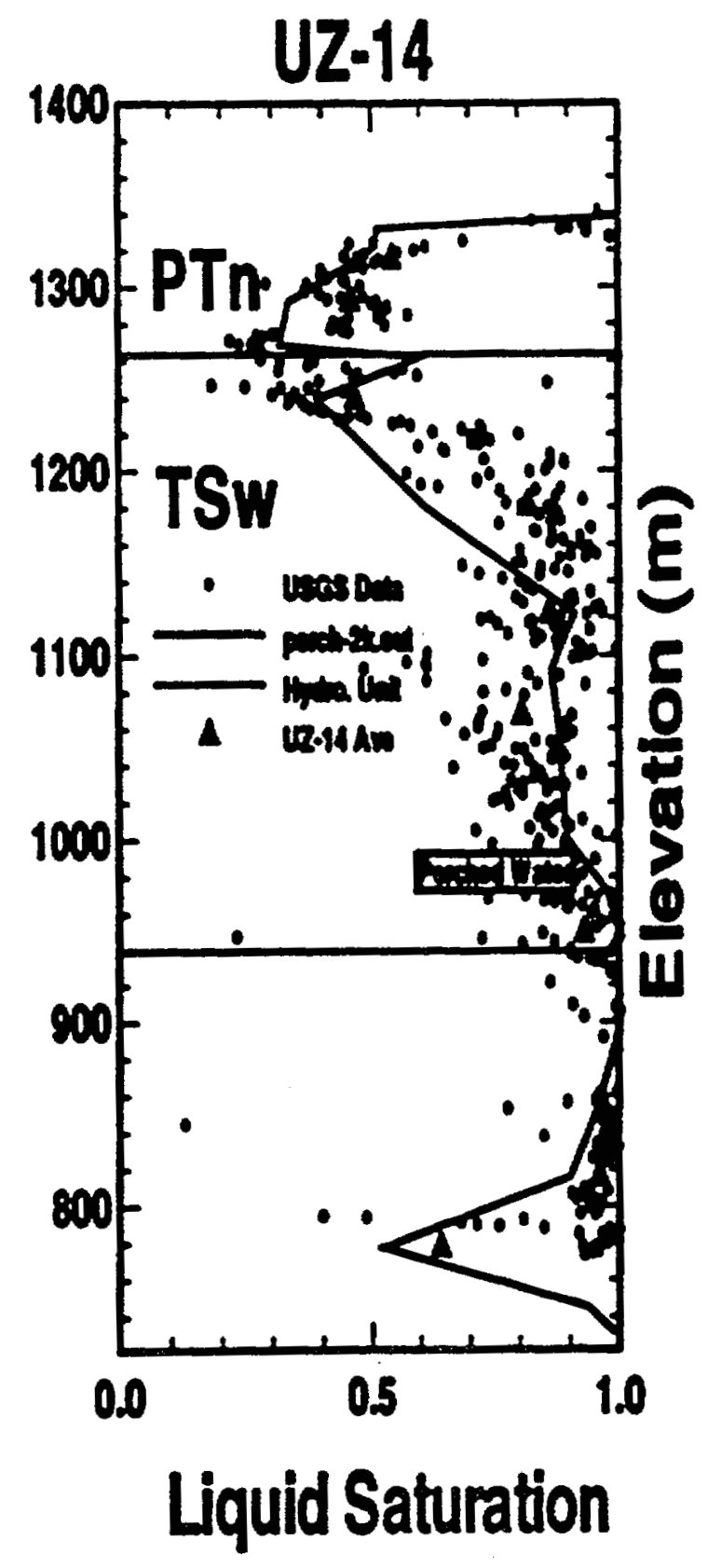

Figure 3 Comparisons of the simulated and observed saturations and perched water locations for Borehole UZ-14. 


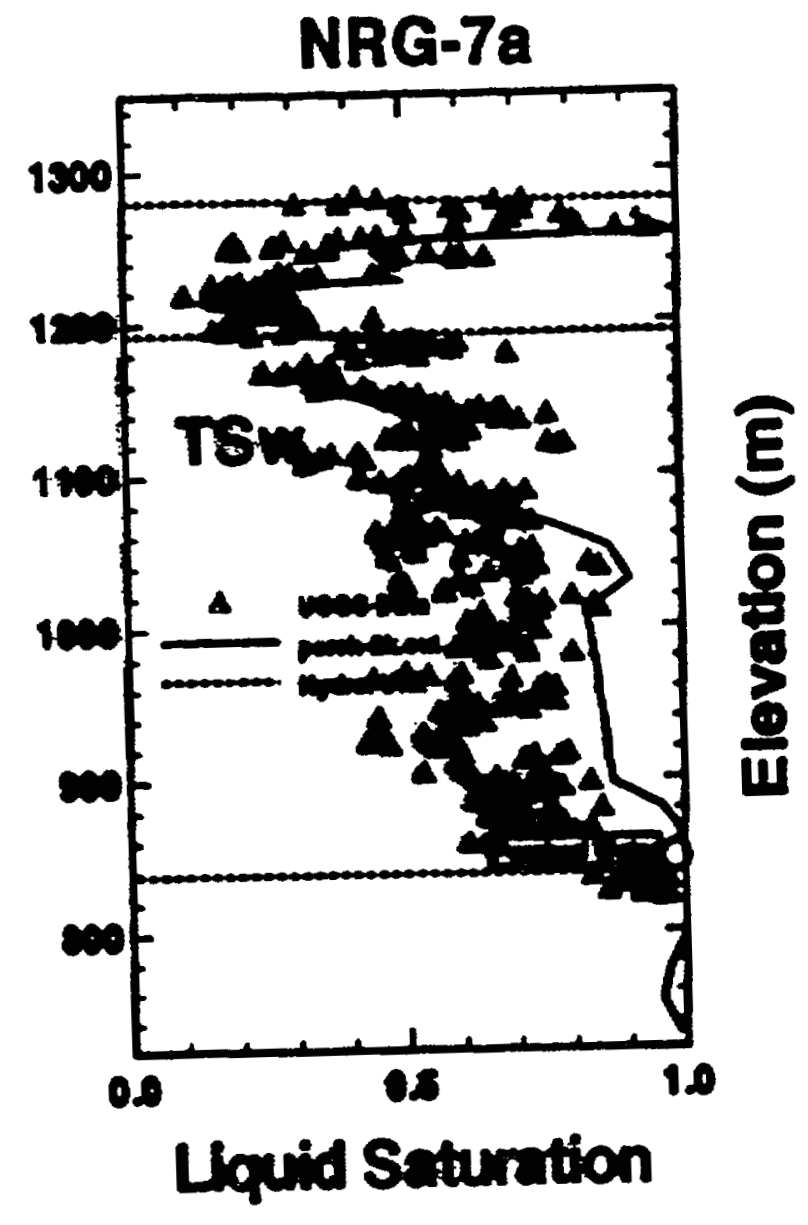

Figure $4 \quad$ Comparisons of the simulated and observed saturations and perched water locations for Borehole NRG-7a. 

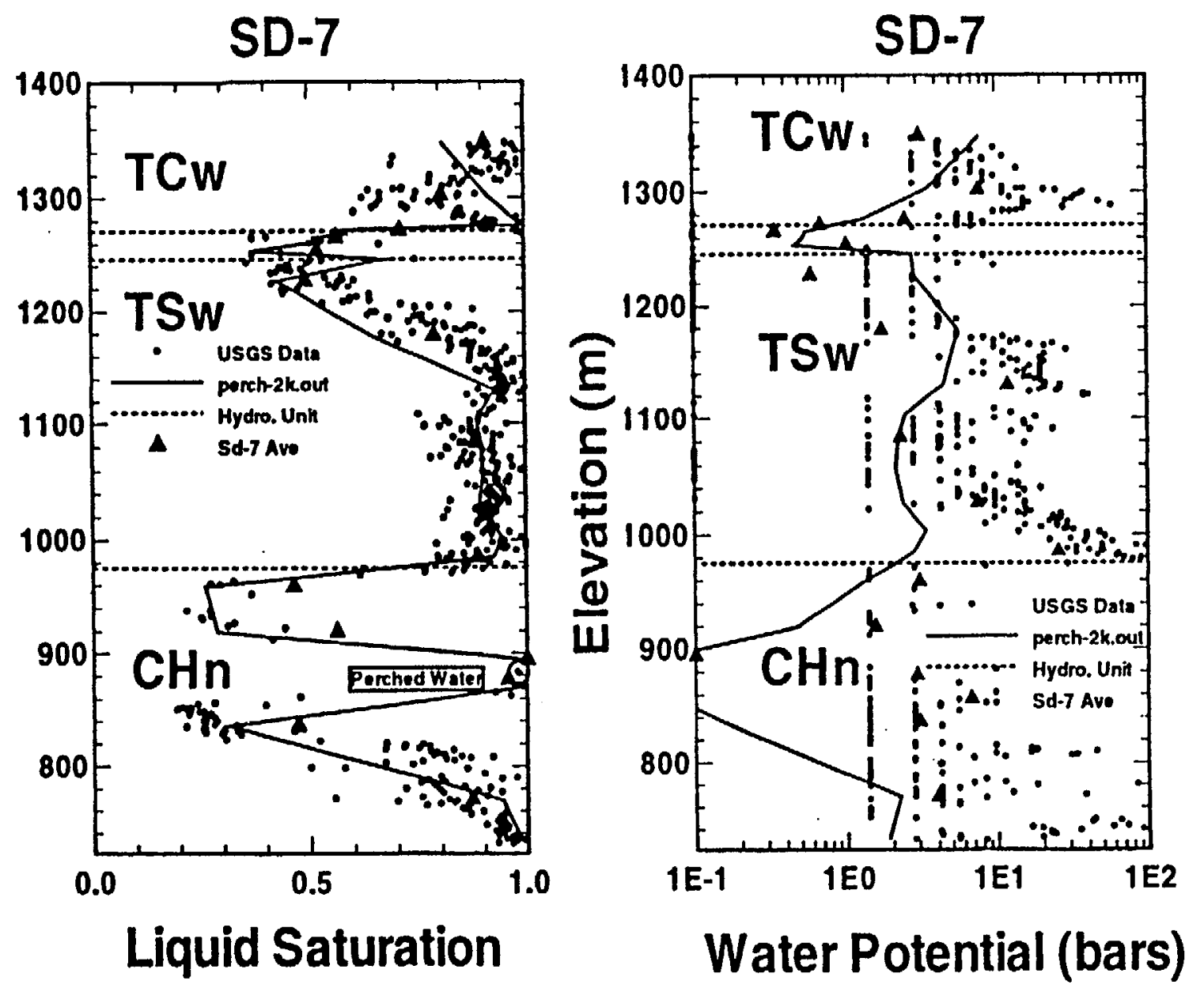

Figure 5 Comparisons of the simulated and observed saturations and perched water locations for Borehole SD-7. 

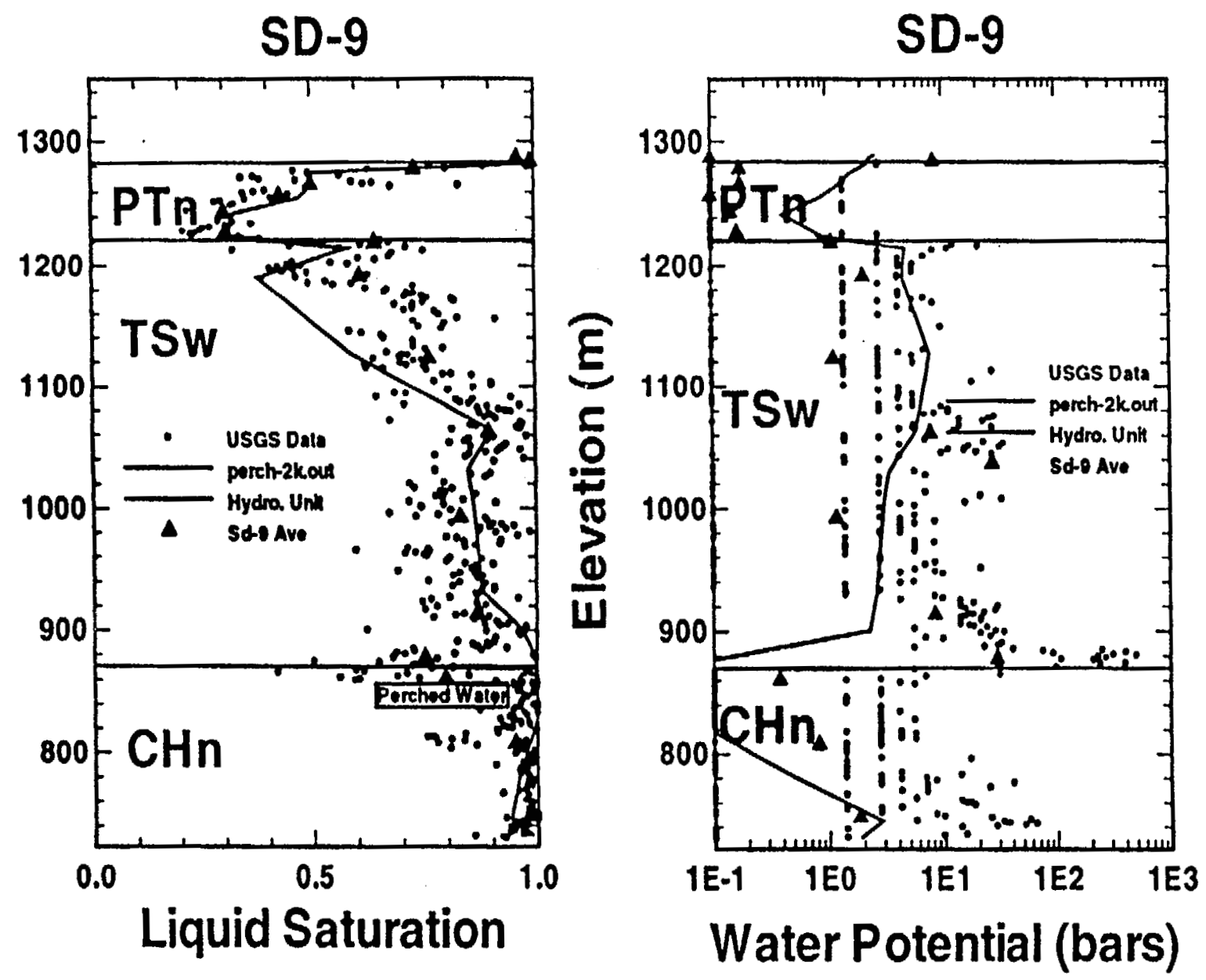

Figure 6 Comparisons of the simulated and observed saturations and perched water locations for Borehole SD-9. 


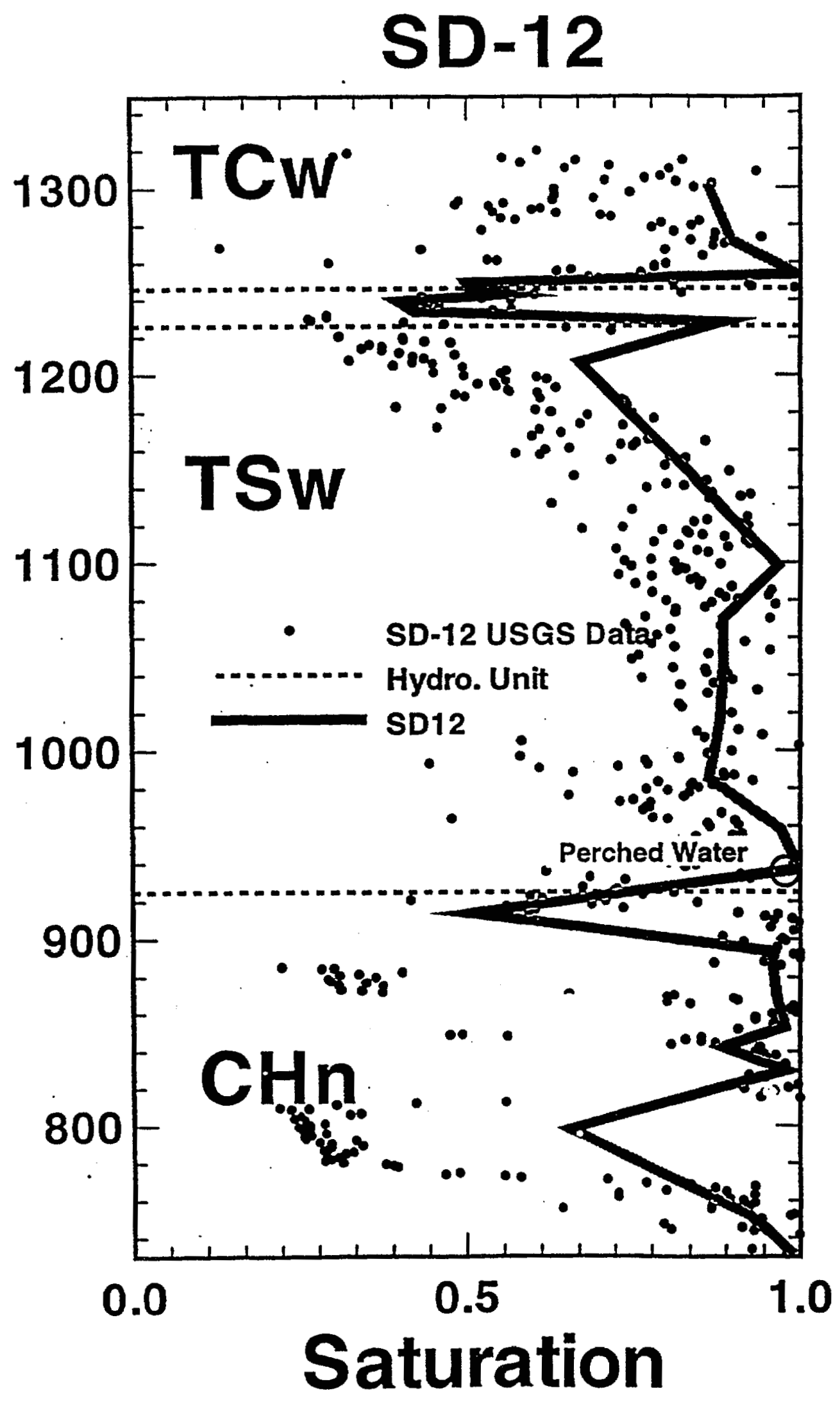

Figure 7 Comparisons of the simulated and observed saturations and perched water locations for Borehole UZ-12. 


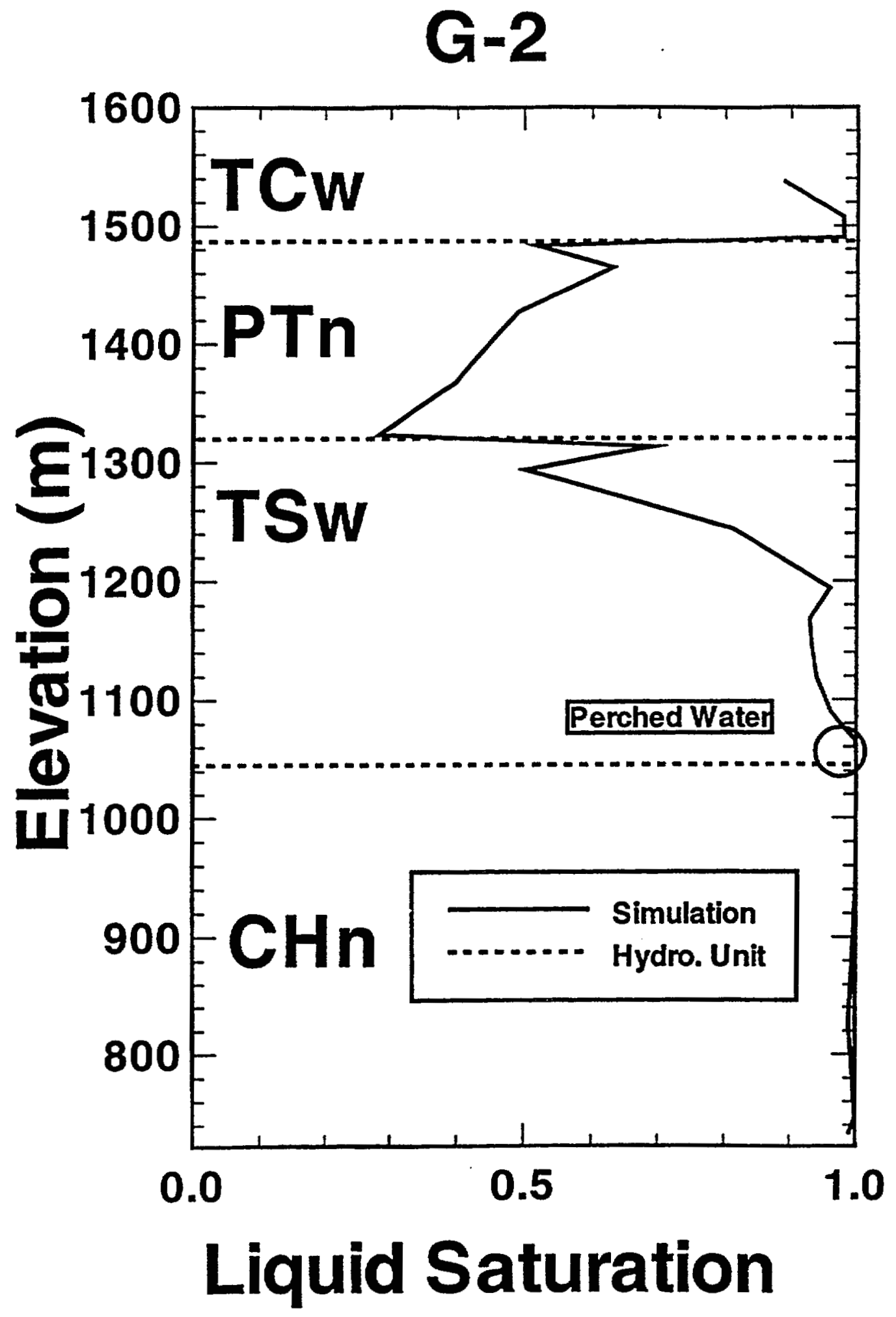

Figure 8 Comparisons of the simulated saturations and observed perched water locations for Borehole G-2. 


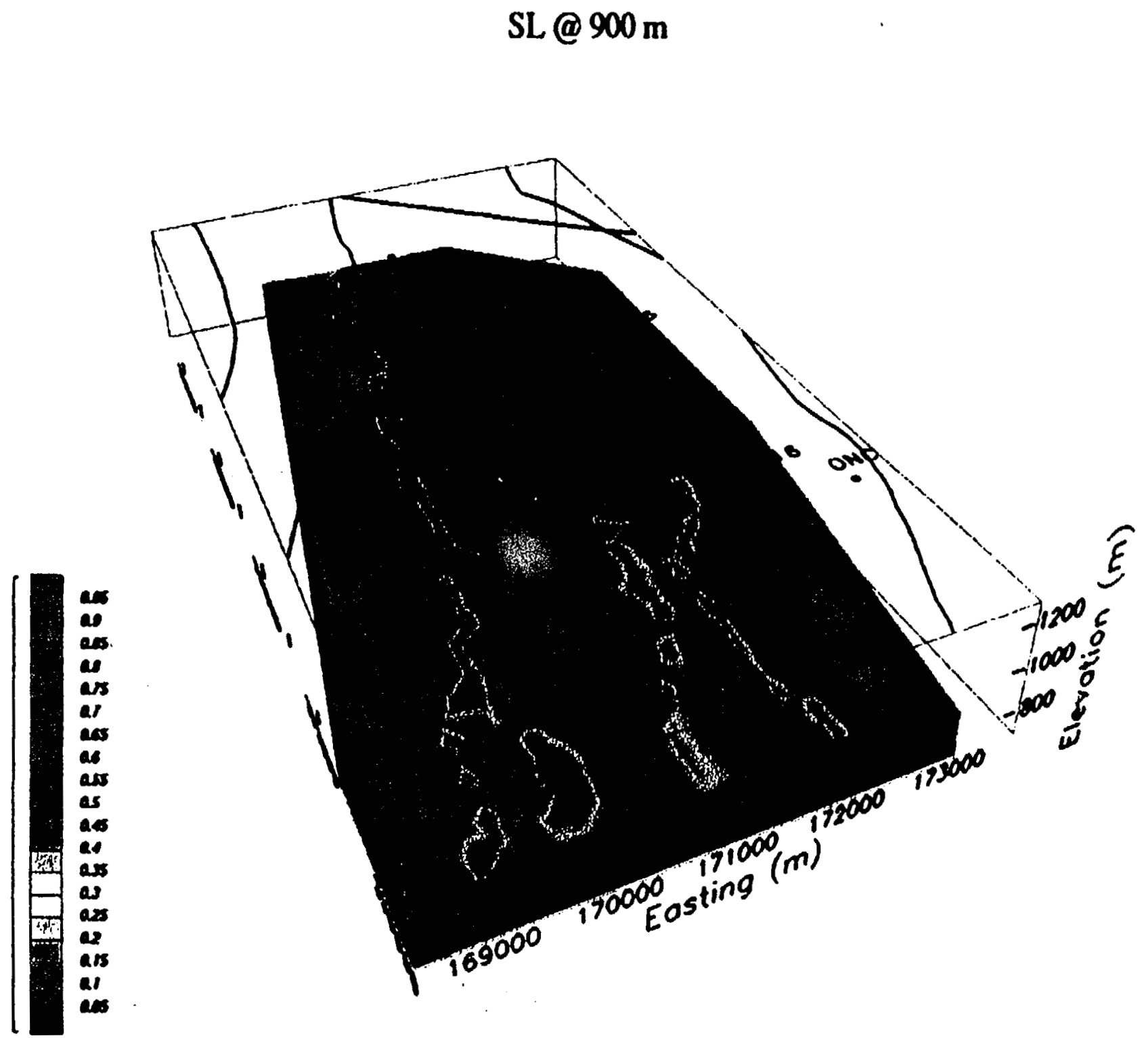

Figure 9 A plan view of 3-D saturation contours showing the perched water body surrounding UZ-1/14, SD-9, NRG-7a, and G-2. 


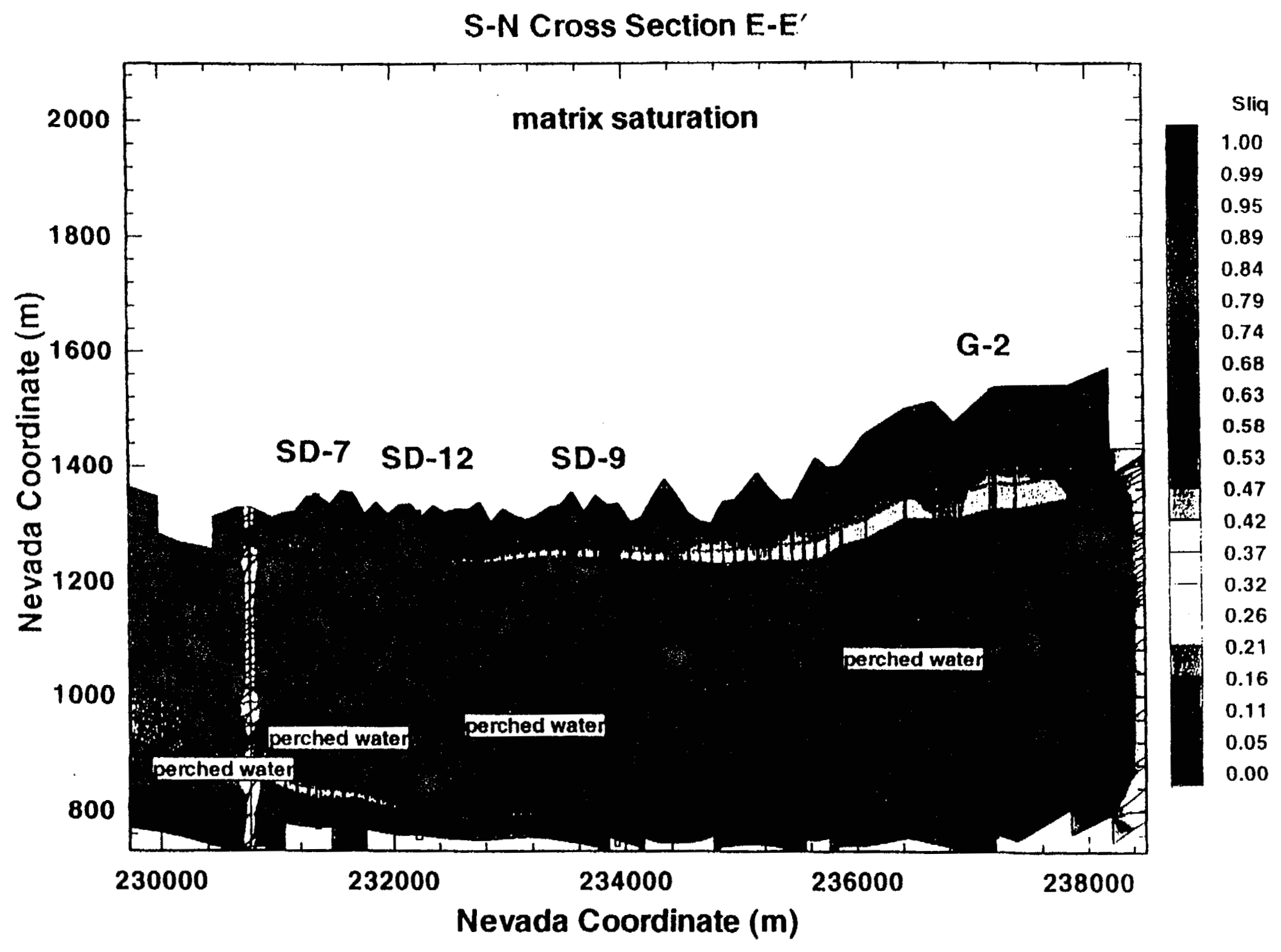

Figure $10 \quad$ Vertical saturation contours along south-north cross-section (E-E) through SD-7, SD-12, SD-9 and G-2 perched water zones. 


\section{E-W Cross Section C-C'}

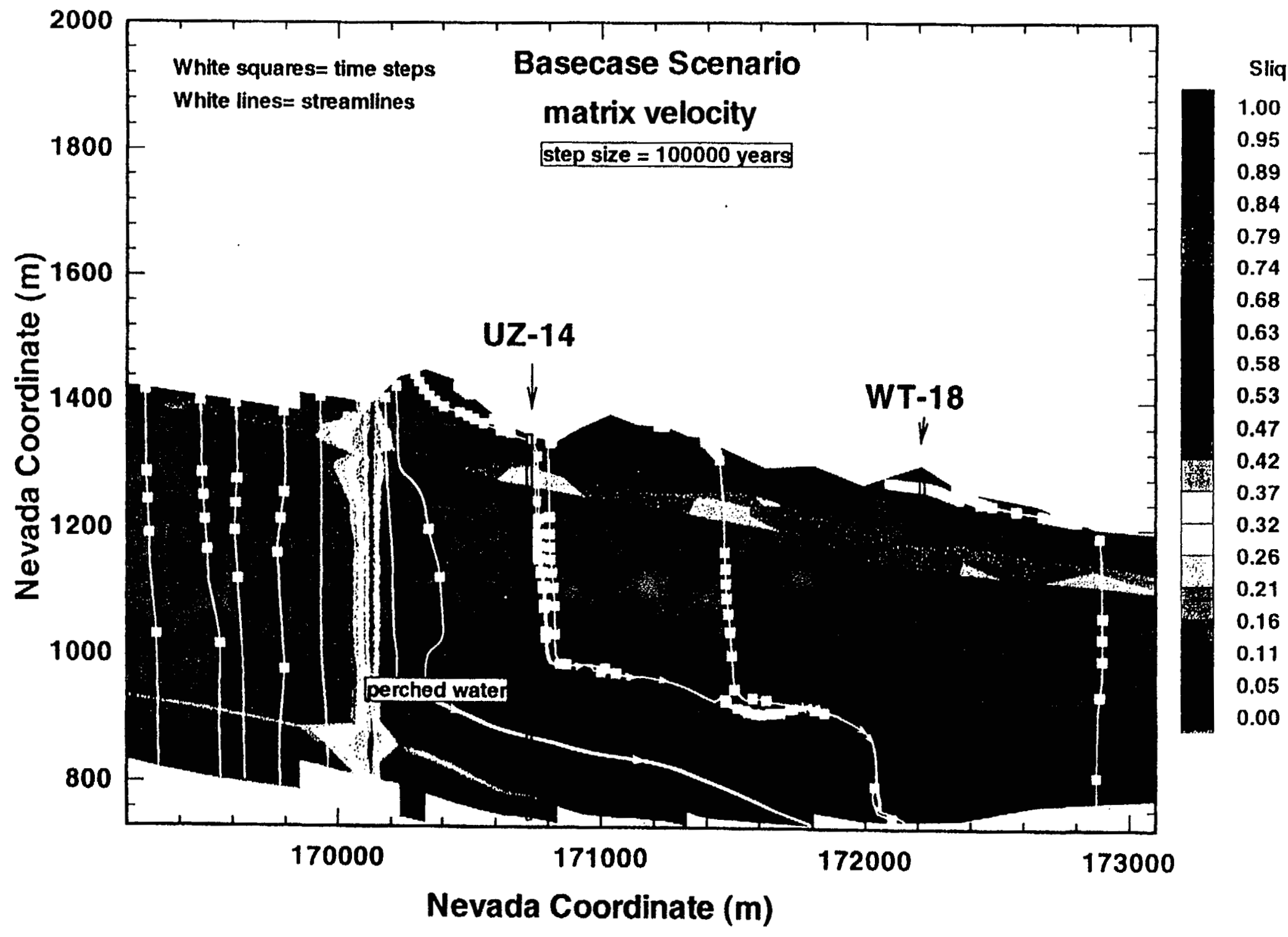

Figure 11 Vertical saturation contours along west-east cross-section (E-E) through the UZ-1/14 water zone. 
UZ-14 Pumping Test \#2

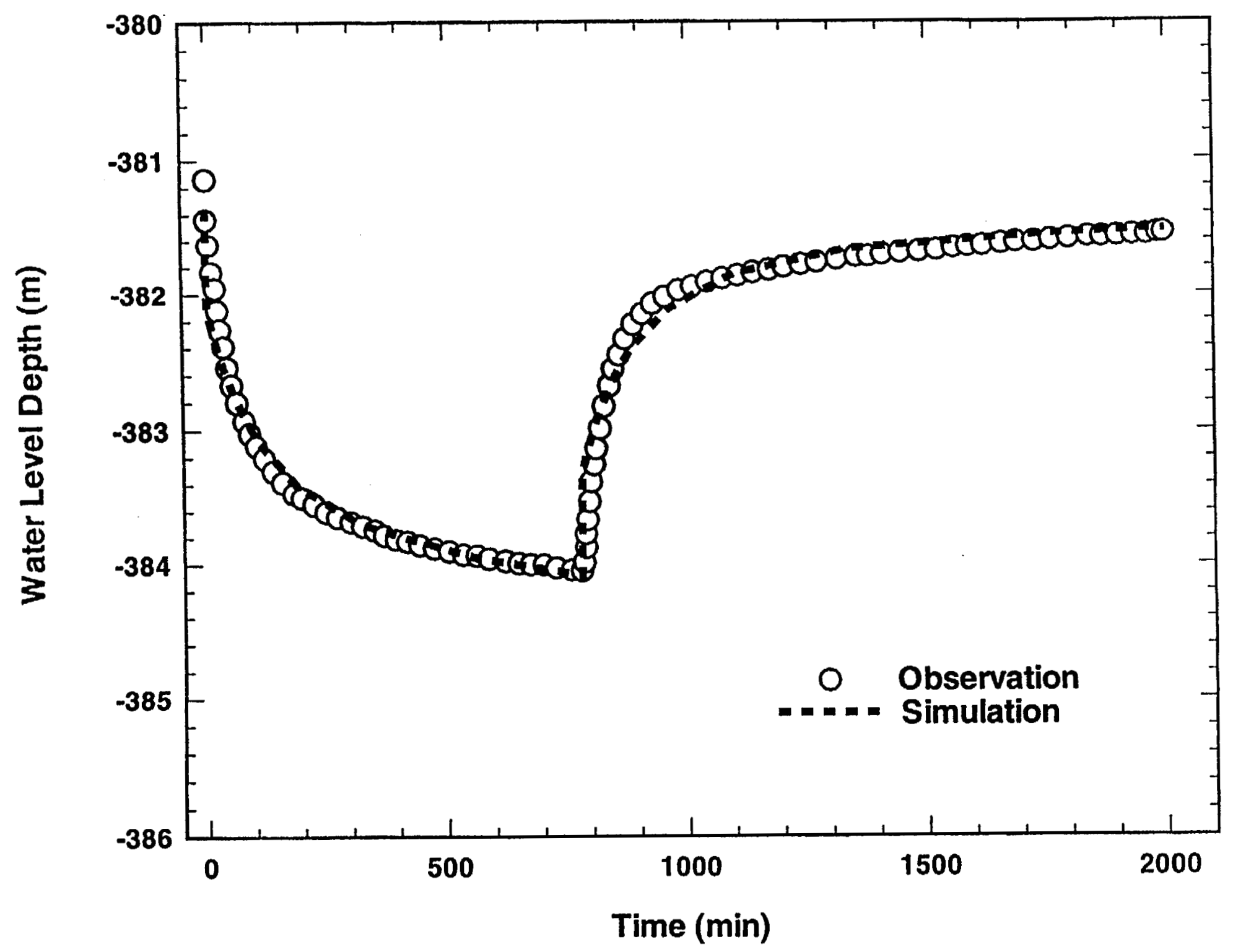

Figure 12 Comparison of the observed and simulated water level drawdown and recovery of Pumping Test 2 of UZ-14. 


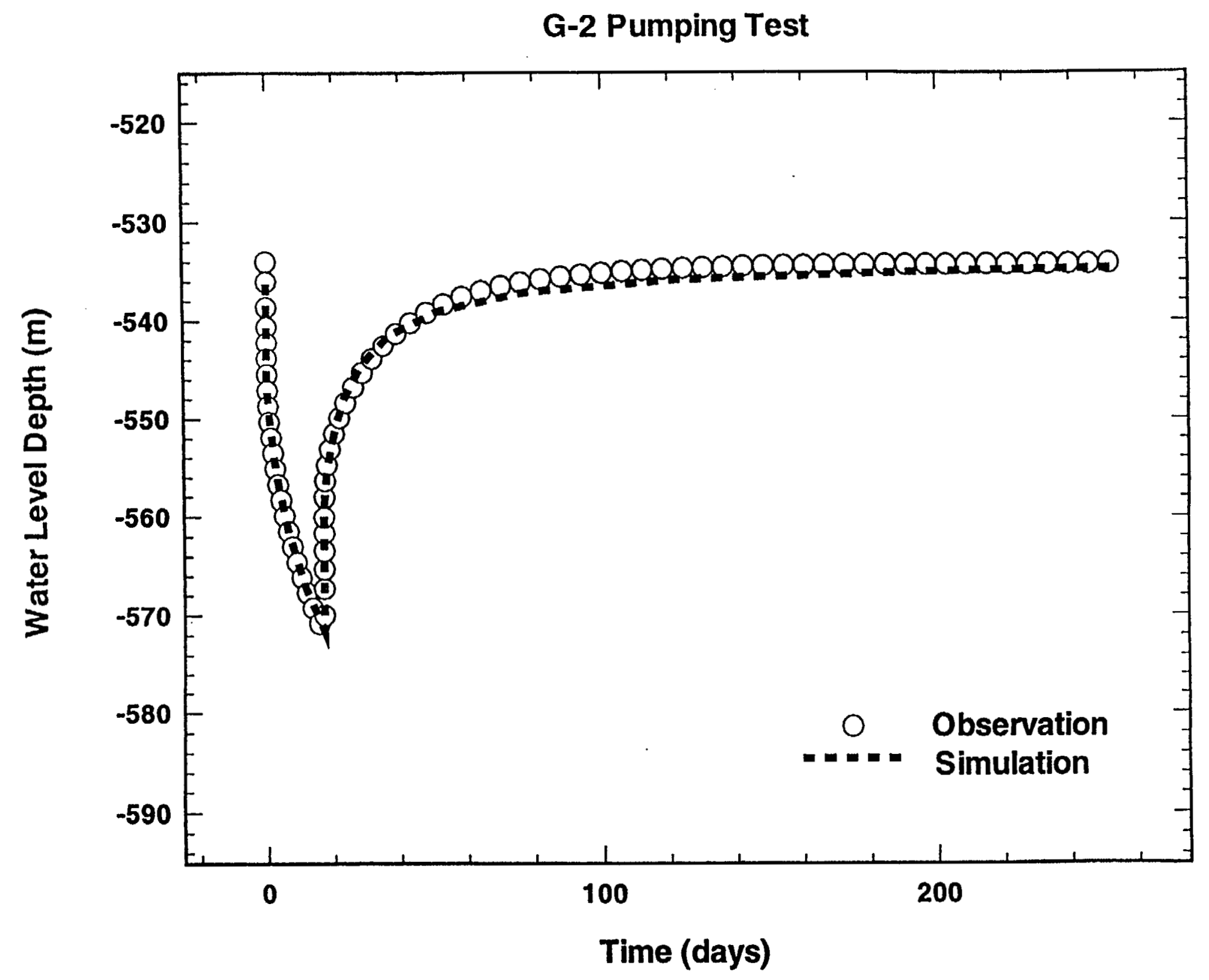

Figure 13 Comparison of the observed and simulated water level drawdown and recovery of pumping of G-2. 